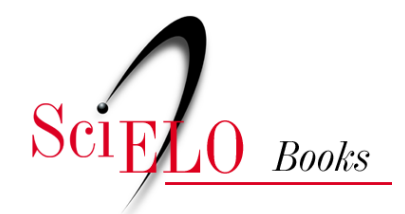

\title{
EDUFU
}

\section{Triângulo Mineiro uma fronteira na Colônia e no Império}

\author{
Luís Augusto Bustamante Lourenço
}

\section{SciELO Books / SciELO Livros / SciELO Libros}

LOURENÇO, L.A.B. Triângulo Mineiro: uma fronteira na Colônia e no Império. In: A oeste das minas: escravos, índios e homens livres numa fronteira oitocentista Triângulo Mineiro (1750-1861) [online]. Uberlândia: EDUFU, 2005, pp. 95-169. ISBN 978-85-7078-516-9. https://doi.org/10.7476/9788570785169.0005.

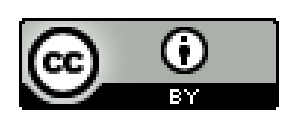

All the contents of this work, except where otherwise noted, is licensed under a Creative Commons Attribution 4.0 International license.

Todo o conteúdo deste trabalho, exceto quando houver ressalva, é publicado sob a licença Creative Commons Atribição $\underline{4.0}$.

Todo el contenido de esta obra, excepto donde se indique lo contrario, está bajo licencia de la licencia $\underline{\text { Creative Commons }}$ Reconocimento 4.0. 


\section{3 | Triângulo Mineiro: uma fronteira na Colônia e no Império}

\section{A diáspora mineira}

Depois de percorrer, maravilhado, o exuberante trecho de Mata Atlântica que se estendia do litoral carioca à vila de Barbacena, em Minas Gerais, o naturalista Auguste de Saint Hilaire (2000) passou a descrever, de Queluz ${ }^{1}$ em diante, um cenário de devastação e abandono que mais lembrava uma paisagem lunar. Entre Ouro Branco e Vila Rica ${ }^{2}$

A paisagem toma um ar de tristeza que conserva quase sempre até Vila Rica. Não se descobrem de todos os lados senão campos desertos, sem cultura e sem rebanhos. Se se avistam algumas casas, ordinariamente estão em ruínas; os contornos das montanhas são ásperos e irregulares; continuamente se avistam escavações para a lavagem de ouro; a terra vegetal foi eliminada, com ela desapareceu a vegetação, e nada mais ficou senão montes de cascalho (SAint Hilaire, 2000, p. 68).

Ao passar por Antônio Pereira, povoado ao norte de Vila Rica, "não se percebe no campo o menor sinal de cultura; não se vê um único rebanho em meio às vastas pastagens que cobrem os morros" (Saint Hilaire, 2000, p. 75). Em Mariana; “os morros nos arredores [...] são estéreis e incultos” (p. 80). Ao passar por Camargos, ao norte de Mariana, viu uma paisagem "rodeada de morros desolados, esburacados pelos mineradores de ouro" (p. 87). Chegando a Catas Altas,

todo o dia se passou sem que lobrigássemos a menor lavoura; [...] sem a presença de uma ovelha ou cabeça de gado sequer; e o que mais freqüentemente chamava

Hoje Conselheiro Lafaiete

2 Hoje Ouro Preto. 
a nossa atenção eram os morros áridos, sulcados em todos os sentidos pelas mãos dos mineradores (SAint Hilaire, 2000, p. 88).

Em Santa Bárbara, a caminho da comarca do Serro do Frio, " "não se observa em seus arredores o menor sinal de cultura; por todos os lados, a terra foi escavada e revolvida pelos faiscadores" (SAINT Hilaire, 2000, p. 98).

Esse espetáculo de devastação ambiental não foi notado só pelo olhar cuidadoso e ilustrado do cientista francês. Os desenhos feitos por Rugendas, retratando as vilas do ouro, na década de 1820, mostram cenários de solos arruinados por voçorocas, ausência de cultivos ou pastagens, morros sem qualquer vestígio de matas (figura 1). Em Santana do Sapucaí, os alemães Spix e Martius observaram:

[...] encontramos lavras de ouro já de considerável extensão. De longe parecem trincheiras cavadas. Nas encostas, formando terraços, estavam abertos fossos de alguns pés de profundidade e de largura, pelos quais era levada a água da chuva pelos flancos abertos do barro vermelho. [...] Tudo dá um aspecto triste de destruição selvagem; as próprias estradas estão danificadas, e essa paisagem entristece o viajante, penosamente (Spix; Martius, 1981, p. 182).

Contemporâneos deles, como o engenheiro alemão Wilhelm von Eschwege (1996) e o general português Raimundo Cunha Matos (1981), tiveram a mesma impressão, e foram unânimes em apontar as causas de um quadro tão desolador: a lavagem dos solos pela mineração, e o sistema agrícola predatório usado pelos mineiros.

O sistema de mineração de ouro e diamantes, usado desde os primeiros anos do século XVIII na região central de Minas Gerais, só agora começa a ter o seu impacto ambiental avaliado pelos estudiosos. De início extraído pela lavagem do cascalho retirado nos aluviões dos córregos, logo o esgotamento desse ouro de aluvião levou os mineiros a iniciarem a exploração do ouro nas encostas dos morros. As florestas eram queimadas e, em seguida, os rios e córregos eram desviados, às vezes, usando-se sistemas de aquedutos com quilômetros de extensão, para que a água erodisse os morros onde se localizavam as jazidas (LunA; Costa, 1982). Os riachos, às vezes, eram voltados diretamente

3 Hoje norte de Minas e Vale do Jequitinhonha. 


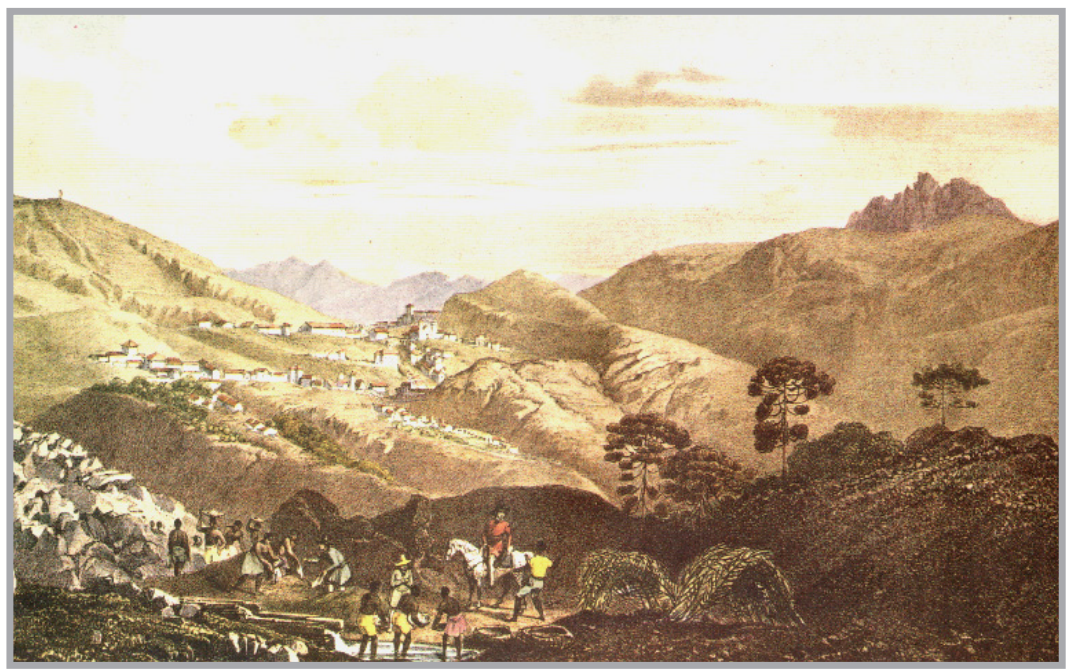

Figura 1: Vila Rica.

Fonte: Rugendas (1998)

contra as encostas, para provocar o desabamento de uma formação rochosa promissora, técnica conhecida como carregar uma montanha em talho aberto. Em outras situações, as encostas eram drenadas a seco, abrindo-se crateras de até 2 metros de profundidade em média (DEAN, 1996). Em poucos meses, os solos eram removidos por um processo erosivo antrópico, praticado sobre grandes superfícies, que eram abandonadas assim que novas lavras eram localizadas.

Tais técnicas exigiam grande vazão de água dos cursos fluviais locais. Daí a face leste da Serra do Espinhaço ter sido a mais atingida por esse tipo de exploração: cobertas pela Mata Atlântica e a barlavento das massas de ar oceânicas, seu regime pluvial permitia que o trabalho de extração aurífera não tivesse que ser interrompido na estação seca (DEAN, 1996).

Estudos atuais tentam estimar a área devastada pela prospecção de ouro e diamantes. Dean (1996) calcula que, se os mineiros obtinham um grama de ouro em um metro cúbico de ganga, em média, é provável que, durante o século XVIII, tenham sido revirados $4.000 \mathrm{~km}^{2}$ de solos de Mata Atlântica. Esse historiador estima a destruição de uma faixa de $450 \mathrm{~km}$ de extensão por 45 km de largura, em média, ao longo da Serra do Espinhaço, estendendo-se de Lavras a Diamantina. 
Solos arrancados pela febre do ouro, deixando imensas voçorocas abertas, cobertas apenas por tufos de mata-pastos. Esta não seria a única causa da catástrofe ambiental que destruiu, apenas no século XVIII, $30.000 \mathrm{~km}^{2}$ de Mata Atlântica, a maior parte em Minas Gerais (DEAN, 1996). Um outro fator também não escapou aos olhos dos observadores estrangeiros de então: o sistema agrícola usado pelos habitantes de Minas Gerais.

A extração aurífera exigiu que, em pouco tempo, já nos primeiros anos do século XVIII, se criasse uma agricultura voltada para o consumo local, na região em torno das lavras. A própria oferta de meio circulante, na forma do ouro em pó, estimulou não só a vinda de comerciantes para a região, mas o surgimento de uma diversificada agricultura e artesanato locais. A agricultura do milho dos primeiros tempos, trazida pelos pioneiros paulistas, foi logo complementada por uma variedade muito maior, com cultivos de feijão, algodão, fumo, cana de açúcar, e criação de porcos e gado (HolAndA, 1985). As fazendas, geralmente, combinavam as lavras auríferas com engenhos de cana, farinha e pecuária (Silveira, 1997).

A febre do ouro atraiu um número muito grande de migrantes para a região, e aqueceu, a níveis nunca vistos, o tráfico negreiro transatlântico. Aproximadamente, 500 mil portugueses emigraram no século XVIII, a maioria para Minas (DeAn, 1996), despovoando regiões inteiras de Portugal, como o Minho (LunA; Costa, 1982). Dez mil moradores do Rio de Janeiro emigraram para as Minas, e os núcleos paulistas e baianos tiveram redução populacional. Em 1763, quando se tornou manifesta a exaustão das lavras, a população da capitania já somava meio milhão de pessoas (HoLANDA, 1985). Esse aumento demográfico causou forte incremento na demanda por produtos da agricultura de subsistência nos níveis local, regional e extra-regional.

Esse quadro criou uma situação demográfica e ecológica que pode ser assim resumida: uma grande população (para os padrões da época) que dependia de uma agricultura de técnicas rudimentares, praticada em solos de mata. Esta agricultura tinha que competir pelos solos com as lavras e, por isso, as áreas cultivadas eram sobrecarregadas, exigindo intervalos de pousio cada vez mais curtos.

O modo como o crescimento demográfico — como nesse caso — impõe as formas de agricultura foi estudado por Marcílio (2000), a partir de uma revisão de autores como Boserup, Clark e Kayser. A autora, ao fazer o estudo 
de caso da capitania de São Paulo do século XVIII, concluiu que o crescimento da população levou à passagem de um sistema agrícola de pousio florestal (20 a 25 anos de pousio das áreas cultivadas, com reconstituição da mata original) para um sistema de pousio arbustivo (6 a 10 anos de pousio, com reconstituição de uma vegetação secundária do tipo herbáceo-arbustivo ou capoeira). Tais sistemas são compatíveis com níveis técnicos bastante rudimentares e sistema itinerante (MARCílIo, 2000).

Uma das conseqüências do uso de sistemas de pousio longo, com baixo nível técnico, é que eram necessárias áreas muito grandes para manter um número relativamente pequeno de famílias. O governador paulista Pimentel, por exemplo, afirmou em resposta a uma consulta do Conselho Ultramarino, que meia légua em quadra (aproximadamente 1.089 hectares) era muito pouco para uma única família de roceiros:

Por que como na mesma terra ou roça que semeiam este ano, o não fazem para o seguinte, mas derrubam e queimam novo mato, e quando se vem chegar ao fim de meia légua, não tem passado o curso, dos anos necessários para que no princípio de meia légua, e primeira roça, tenham crescido novas árvores e lenhas para se tornarem a roçar e queimar, e por esta causa deixam os lavradores as tais terras, a que chama capoeiras e procuram outras ou por sesmarias, ou por compra em que possam continuar as suas granjerias e plantas (MARCílio, 2000, p. 168).

Um crescimento demográfico ainda maior poderia gerar três situações distintas entre as populações agricultoras: aumentos na produtividade com redução ainda maior do tempo de pousio, na condição de se contar com técnicas mais avançadas; fome e tensões sociais; ou emigração para regiões de fronteira. Esta terceira situação foi a mais comum, no caso estudado pela autora.

Marcílio afirma que, a partir de meados do século XVIII, houve a passagem, em várias regiões do território paulista, do pousio florestal para o arbustivo. Isto se deu por causa do aumento da população paulista, de 15.000 habitantes no final do século XVII, para $169.544 \mathrm{em} \mathrm{1800.} \mathrm{A} \mathrm{partir} \mathrm{daquele}$ período, novos aumentos demográficos estimularam a emigração, em busca de novas terras, para o Vale do Paraíba, o Oeste Velho (região de Campinas e Mogi-Guaçu), e para os campos do Paraná e Santa Catarina. 
Ainda não existem estudos semelhantes para o caso mineiro, mas podemos inferir que, na agricultura praticada em Minas Gerais, se deu a mesma seqüência de eventos que em São Paulo, numa escala muito maior. Antonil (1997) estimava em 30.000 o número de mineiros no início do século XVIII. O levantamento demográfico da capitania feito pelo desembargador Teixeira Coelho, em 1776, somava 319.769 habitantes (Cunha Matos, 1981). Trinta e cinco anos depois, o mapa demográfico feito por Eschwege (1996) totalizava 514.107 habitantes. Dito de outra forma, Minas Gerais iniciou o século XVIII com uma população que já era o dobro da de São Paulo, e o terminou com uma população cinco vezes maior que a daquela capitania. É provável, por isso, que as pressões exercidas pela demanda por alimentos sobre os cultivos em solos de mata fossem ainda maiores do que naquele caso.

Os relatos deixados pelos viajantes joaninos permitem concluir que o sistema agrícola utilizado na região central de Minas era semelhante ao analisado por Marcílio para o caso paulista. Saint Hilaire (2000) assim o descreve:

Quando já se fizeram duas colheitas em um solo outrora coberto de matas virgens, deixa-se o terreno repousar um pouco; brotam aí árvores muito mais delgadas que as primeiras. [...] deixam-se estas crescer durante cinco, seis ou sete anos, segundo as regiões; cortam-se, novamente, queimam-se em seguida, e faz-se a plantação nas cinzas. [...] quando, nessa parte do Brasil, um terreno já foi cultivado umas poucas vezes, vê-se nascer uma samambaia imensa [...] [e] uma gramínea viscosa, pardacenta, chamada capim-gordura [...]. O agricultor, não mais podendo esperar ver nascer árvores sobre o seu terreno, diz que este está definitivamente perdido (é terra acabada); após fazer sete ou oito colheitas em um campo, ele o abandona, e queima outras matas, que em breve têm a mesma sorte das precedentes (Saint Hilaire, 2000, p. 90-91).

No caso mineiro, contudo, pressões demográficas maiores sobre uma superfície agricultável relativamente menor, por causa das superfícies que tiveram os solos removidos pelas lavagens da mineração, levaram a uma superutilização das áreas de cultivo, refletindo-se num encurtamento do período de pousio. O Barão de Eschwege resumiu, numa de suas anotações, o que ocorria com os solos mineiros, ao falar dos arredores de Vila Rica: 
Cada solo exige longo período de descanso, conforme o grau de fertilidade que possui, antes que se possa replantar. Esse prazo é indicado pelo crescimento da capoeira, que se desenvolve depressa e alcança boa altura. Assim, o replantio, nesse caso, pode ser feito após oito anos. Em outras regiões, esse prazo pode estender-se até a doze, quinze e vinte anos. O agricultor que não respeitou esses limites e plantou, por exemplo, 20 alqueires em área suscetível de apenas 10 , acaba por transformar sua terra fértil em árida estepe, onde brotam apenas samambaia e caniço, como é o caso da maioria dessas regiões (EsCHWEGE, 1996, p. 64).

Noutras palavras, as grandes demandas, impostas pela população urbana dos arraiais e vilas do ouro, pressionavam pelo encurtamento do pousio e superutilização dos solos, mantendo-se, contudo, as técnicas rústicas do sistema itinerante. O resultado era um nível de esgotamento tal que impedia até mesmo a reconstituição da capoeira. Segundo Dean:

A maior densidade de população incentivava a redução do intervalo entre queimadas nas fazendas das vizinhanças de minas e vilas maiores. [...] o crescimento da floresta secundária nessas áreas, em conseqüência, fica em uma fase bastante imatura, e reforçava a tendência de que ela não mais voltasse a crescer. [...] a degradação de grande parte dos solos das áreas derrubadas estava acontecendo a tal ponto que a vegetação que renascia carecia de muitas das espécies que teriam reconstituído, na ausência de interferência humana, a floresta original (1996, p. 116).

Com o esgotamento dos solos nas proximidades das vilas do ouro, ocorreu um progressivo afastamento entre as áreas produtoras de alimentos e as áreas mineradoras. Em 1816, Vila Rica era abastecida por áreas produtoras situadas no vale do rio Paraopeba, a $100 \mathrm{~km}$ de distância, pois, próximo àquele núcleo, já não existiam mais terras cultiváveis (Eschwege, 1996). Saint Hilaire, em 1819, escreveu que "os morros dos arredores de Mariana são estéreis e incultos, e os gêneros que se consomem na cidade vêm de grande distância” (2000, p. 80).

Da mesma forma que no caso paulista, estudado por Marcílio, também aqui o aumento das tensões demográficas impôs aos agricultores a emigração para áreas de fronteira, diante da inexistência da opção pela intensificação dos 
cultivos com o avanço técnico. Tal imigração, contudo, deu-se em proporções mineiras e não paulistas, isto é, contando com uma população migrante muito maior. Um grande (e pouco estudado) movimento centrífugo de população, talvez o maior até então visto, tendo como área de repulsão a região mineradora da capitania de Minas Gerais, iniciou-se, a partir da década de 1760, em direção a todas as regiões circunvizinhas. As demais comarcas de Minas Gerais e as capitanias (depois províncias) de São Paulo, Rio de Janeiro, Mato Grosso e Goiás receberam grandes levas desses migrantes, em sua maioria, roceiros em busca de terras para cultivo e pastagens.

Tais migrantes, como aparece nos documentos de época, eram chamados geralistas pelas populações locais. O mapa mostrado na figura 2, produzido com base na revisão de estudos realizados por outros autores, que abordaram frações desse fluxo migratório em casos regionais, resume a área abrangida por essa dispersão populacional. Esse movimento centrífugo teve longa duração: iniciado em 1760, só se interrompeu nas primeiras décadas do século XX (PRADO JR., 1986).

O esgotamento das jazidas superficiais de ouro e diamantes, a partir de 1750, causou decréscimo populacional em alguns arraiais e vilas da região central de Minas, principalmente naquelas cujas atividades de comércio e serviços eram alimentadas exclusivamente pelo ouro das lavras. Saint Hilaire, ao passar por Queluz, observou que "o mato aí cresce por todos os lados; casas bastante lindas nos pareciam estar abandonadas, e quase todas estavam mal conservadas a ponto de cair em ruínas" (Saint Hilaire, 2000, p. 65). Em Santa Bárbara, "é fácil perceber que teve outrora grande importância; mas esse vilarejo está de tal forma abandonado, que um proprietário que aí possui várias casas garantiume que ninguém queria habitá-las, mesmo de graça” (Saint Hilaire, 2000, p. 98). Em Conceição do Mato Dentro, “o mato que cresce nas ruas esconde quase completamente as pedras do calçamento; grande número de casas já foi abandonado, e as outras caem em ruínas" (Saint Hilaire, 2000, p. 135).

O abandono de alguns núcleos, com o esgotamento das lavras e dos aluviões auríferos, e o abandono das fazendas cujos solos haviam se esgotado, ou sido destruídos pelos métodos hidráulicos de mineração, levaram a comarca de Ouro Preto a um decréscimo demográfico pela emigração, ao longo da segunda metade do século XVIII e início do século XIX. Isso pode ser comprovado pelas estimativas demográficas compiladas por Cunha Matos (1981), que mostram uma perda de população absoluta de 5.573 habitantes, entre 1776 e 1829 . 


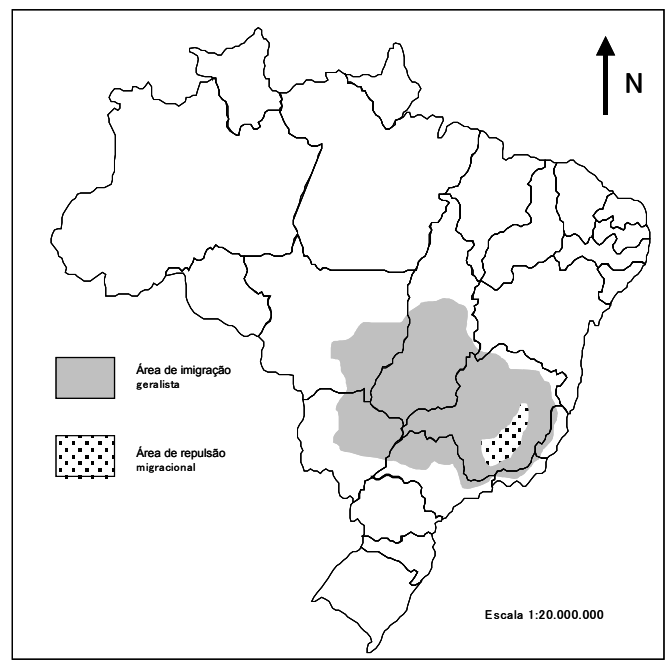

Figura 2: migração geralista entre 1760 e 1890

Fontes: Prado jr. (1986), Palacin e Moraes (1994), Monbeig (1998), Sodré (1941).

No entanto, isso não significou a "decadência" da economia mineira, como interpretaram alguns autores. Enquanto a atividade mineradora perdia fôlego e os solos da zona aurífera se exauriam, outras regiões, como a comarca de Paracatu, do Serro Frio e principalmente a do Rio das Mortes, viram prosperar uma importante economia agropastoril e manufatureira. É o que veremos a seguir.

\section{O mito da decadência mineira e a montagem de uma economia agropastoril}

Delineado esse quadro, que entendemos estar por trás dos fatores que levaram à emigração de geralistas para as zonas de fronteira, duas ressalvas devem ser feitas. Em primeiro lugar, nem todos os núcleos urbanos da região mineradora se despovoaram com a emigração. Aqueles que conservaram a condição de capital administrativa ou religiosa e, principalmente, os que estavam estrategicamente situados de forma a tornarem-se núcleos comerciais, 
não decresceram - e até mesmo prosperaram — no período em questão. No primeiro caso, encontra-se Vila Rica e Mariana, respectivamente, as capitais administrativa e religiosa da capitania (depois província) de Minas Gerais. Vila Rica, por exemplo, na década de 1820, contava com aproximadamente 8.000 habitantes, dos quais $92 \%$ se ocupavam em atividades urbanas de artesanato e serviços, e destes, 23\% eram funcionários da administração civil, eclesiástica e militares (LunA; Costa, 1982).

O melhor exemplo de dissociação entre um entorno rural $/$ minerador decadente e uma próspera paisagem urbana, no início do século XIX, era São João Del Rei. Antigo núcleo aurífero, capital da comarca do Rio das Mortes, tornara-se, juntamente com a vila de Barbacena, uma das cidades mais importantes da província de Minas Gerais, na primeira metade do século XIX. O viajante inglês Alexander Caldcleugh, entre Santa Rita ${ }^{4}$ e São João Del Rei, comentava que, por quinze quilômetros, percorrera "uma região escalvada e deserta, cujo terreno está todo minado pelas escavações do ouro" (DEAN, 1996, p. 114). As pastagens em torno de São João ${ }^{5}$ eram tão impraticáveis que Saint Hilaire teve que parar sua tropa no Rancho do Marçal, a alguns quilômetros de distância. Mas, ao chegar àquela vila, surpreendeu-se com seu aspecto de prosperidade e abastança:

As ruas de São João são geralmente calçadas e muito largas. Segundo o uso da região, as casas são baixas; mas são em geral bonitas, bem cuidadas, e um grande número entre elas possui um andar além do térreo. [...] Vêem-se, em São João, principalmente na Rua Direita, um grande número de lojas, geralmente muito bem sortidas. Não somente esta vila não tem esse ar de tristeza e abandono, peculiar a quase todas as desta província; não somente não se vêem, a cada passo, casas abandonadas caindo em ruínas, mas ainda tudo aí parece vivo e animado (1974, p. 111).

As impressões de Pohl foram igualmente positivas: "esta cidade figura entre as mais limpas e alegres que já encontrei no Brasil” (1976, p. 86). Spix e Martius assim a descreveram:

\footnotetext{
4 Hoje Ritápolis.

5 Usaremos às vezes, como faziam os viajantes joaninos e como faz hoje a população sanjoanense, apenas o termo São João para nos referirmos a São João Del Rei.
} 
Ruas calçadas, belas igrejas guarnecidas com pinturas de artistas nacionais, lojas fornecidas de todos os artigos de luxo e do comércio europeu, muitas oficinas, indicam a riqueza do lugar que, por suas transações com o sertão, é considerado entre os mais animados do Brasil (SpIX; MarTius, 1981, p. 194).

Assim, nesse caso (e como veremos adiante, também no de Oliveira), a prosperidade do núcleo urbano não se ligava ao entorno rural, aliás, devastado como de resto toda a região aurífera, e sim ao fato de deter a primazia do comércio sobre uma ampla rede de arraiais, que se irradiava pelo sertão a oeste. Analisaremos mais detidamente o comércio sanjoanense do século XIX, e suas relações com o sertão do Triângulo Mineiro, no capítulo 6.

Outra ressalva importante é que não compartilhamos da idéia da "decadência", que teria se seguido ao esgotamento da mineração aurífera e diamantífera em Minas Gerais. A idéia da decadência mineira é, na realidade, muito antiga, e já estava presente no discurso ilustrado das elites mineiras do final do século XVIII, que contrapunham a decadência de seus dias a um passado glorioso, dos tempos de apogeu econômico e cultural, que supostamente teria se dado até meados do século (SiLveIrA, 1997).

A idéia da decadência acabou sendo incorporada por autores como Celso Furtado, pois coadunava com a Teoria dos Ciclos e com a concepção de Sistema Colonial:

Não se havendo criado nas regiões mineiras formas permanentes de atividades econômicas — à exceção de alguma agricultura de subsistência - era natural que, com o declínio da produção do ouro, viesse uma rápida e geral decadência. [...] Ao contrário do que ocorria no caso da economia açucareira [...] na mineração a rentabilidade tendia a zero e a desagregação das empresas produtivas era total. Muitos dos antigos empresários transformaram-se em simples faiscadores e com o tempo revertiam à simples economia de subsistência. Uns poucos decênios foi suficiente para que se desarticulasse toda a economia da mineração, decaindo os núcleos urbanos e dispersando-se grande parte de seus elementos numa economia de subsistência, espalhados por uma vasta região em que eram difíceis as comunidades e isolando-se os pequenos grupos uns dos outros (FURTADO, 1987, p. 84-86). 
Tal idéia foi, contudo, refutada por Sérgio Buarque de Holanda (1985). O historiador paulista afirmou que, ao contrário, durante o meio século de exploração aurífera desenvolveram-se paralelamente atividades agropecuárias de grande importância, estimuladas pela própria presença do ouro como meio circulante, e voltadas para o mercado interno. Kenneth Maxwell, na mesma vertente, escreveu:

A economia regional, com suas propriedades rurais horizontalmente integradas, era particularmente capaz de absorver o choque das transformações que vieram após a exaustão do ouro aluvial. Tanto tinha capacidade para corresponder ao estímulo recebido da economia interna quanto do amplo comércio exterior que fluía pela estrada do Rio de Janeiro e que minguou na proporção direta do declínio da produção aurífera (Maxwell, 1978, p. 112).

Libby (1988), na mesma linha, mostra que Minas manteve o maior plantel de escravos de todas as províncias do Império ao longo do século XIX, e que o crescimento demográfico fora constante no período. Em seu trabalho, demonstra que houve, na verdade, uma substituição das atividades mineradoras pelas agropastoris e artesanais. Segundo esse autor, a economia mineira do século XIX sustentava-se por uma agricultura mercantil de subsistência, voltada em parte para o autoconsumo, e em parte para o mercado interno. Além dessa agricultura mercantil, havia um setor formado por atividades de transformação: fios e panos, oficinas artesanais, pequenas e médias manufaturas, voltadas sobretudo para o mercado do Rio de Janeiro.

Em resumo, não houve colapso econômico com o esgotamento da mineração porque já se encontrava em funcionamento, há muito tempo, uma estrutura produtiva bastante diversificada, e que obtinha a maior parte de sua renda em atividades agropastoris e manufatureiras. Silveira (1997), examinando os documentos das devassas civis do Museu da Inconfidência, concluiu que, em Vila Rica e freguesias próximas, ao final dos Setecentos, 65\% das ocupações estavam voltadas para a economia com vistas ao mercado local, contra $15 \%$ para a mineração. $\mathrm{O}$ autor mostra o quadro de uma economia mineira diversificada, onde as fazendas combinavam a lavra do ouro com engenho de cana, ou com a pecuária. A exploração aurífera era uma das atividades das quais os fazendeiros mineiros lançavam mão, e isto desde meados do século XVIII. Nas palavras 
de Gorender, "há muito tempo, Minas Gerais não era somente mineração de ouro e de diamantes" (1988, p. 465).

A exploração aurífera, atividade pioneira que impulsionou a colonização das Minas, realmente se esgotou, mas esse esgotamento não interrompeu o processo de transformação da capitania num dos principais produtores de gêneros destinados ao abastecimento do litoral, especialmente do Rio de Janeiro. Meio século de extração aurífera foi capaz de criar uma economia regional diversificada e integrada a outras regiões da colônia, capaz de resistir ao esgotamento dos filões. A exaustão das minas e dos solos agricultáveis da comarca de Ouro Preto apenas fez deslocar geograficamente o centro gravitacional da economia mineira para a florescente comarca do Rio das Mortes. ${ }^{6}$

As áreas de fronteira daquela comarca — o Sul Mineiro e a área fronteiriça à capitania do Rio de Janeiro - foram povoadas pelos geralistas, emigrados da zona aurífera, já na segunda metade do século XVIII. Nessa época, afrouxavase o controle dos interstícios em torno das minas, onde a colonização era, até então, proibida (VASCONCELOS, 1999). Ali, tornaram-se criadores de gado, e já em 1765, desciam boiadas para o Rio de Janeiro (GORENDER, 1988).

De início, como já foi visto, a expansão sobre essas regiões fora o resultado da itinerância da agricultura de abastecimento interno da capitania, que já não mais podia contar com os solos dos arredores das vilas do ouro. Como o despovoamento dos núcleos mineradores coincidiu com a ascensão do Rio de Janeiro à condição de principal porto e cidade do Brasil, principalmente após a transferência da Corte portuguesa em 1808, para lá passaram a ser drenados os excedentes produzidos pela comarca. Estes tomavam a forma não só das boiadas, mas também das porcadas, dos carregamentos de toicinho e de couros, e dos panos de algodão, produzidos pelo artesanato doméstico (FraGoso, 1998).

Nessa mesma época, a migração geralista também tomava o rumo oeste, ultrapassando a barreira das montanhas, o vale do rio São Francisco, e avançando sobre o domínio biogeográfico do Cerrado. Levavam consigo as práticas e técnicas de pecuária e agricultura desenvolvidas, por quase um século, no planalto mineiro, e que iriam sofrer um rápido processo adaptativo ao novo ambiente.

Havia ali, contudo, um poderoso empecilho à corrente migratória ocidental dos geralistas: uma importante rede de quilombos, formados pelos

Hoje Sul de Minas e Zona da Mata Mineira. 
escravos, que, durante um século, haviam fugido dos arraiais e vilas do ouro. Do enfrentamento entre esses quilombos e o poder colonial, falaremos em seguida.

\section{A guerra contra os quilombos}

Em 1736, no apogeu da Idade de Ouro de Minas, o governador da capitania, Gomes Freire de Andrade, seguindo ordem régia, iniciou a abertura de um caminho ligando as minas goianas a São João Del Rei e Vila Rica, passando pelas recém descobertas minas do Paracatu (VAsconcelos, 1999). Esse caminho ficaria conhecido como a Picada de Goiás, e deveria tirar o ouro goiano da influência de São Paulo e dos contrabandistas, pondo-o diretamente sob controle da fiscalização instalada em Minas e drenando-o para o Rio de Janeiro. Logo depois, em 1737, Gomes Freire concedeu várias sesmarias ao longo da picada aos homens que se haviam consorciado ao governo da capitania na sua abertura (VAsconcelos, 1999). ${ }^{7}$ Com a Picada, a Estrada do Anhanguera entraria em decadência relativa, pois o tráfego goiano passou a se fazer quase todo pela estrada mineira, e o tráfego cuiabano vivia o auge da navegação das monções (BACELAR; BRIOSCHI, 1999).

O povoamento ao longo da estrada não se daria ainda desta vez. A partir da década de 1740, apesar de as pressões demográficas já se fazerem sentir na zona mineradora de Minas, e o esgotamento do ouro obrigar os mineiros à busca de novos veios, havia um fator que impedia o início da ocupação colonial do Oeste Mineiro: toda a faixa de terras do alto São Francisco e médio rio Grande encontrava-se povoada por quilombos. Pelas informações do padre Diogo de Vasconcelos, foi possível mapear a localização aproximada desses quilombos (figura 3). Formavam um crescente sobre as serras da Marcela, da Saudade, o Campo Grande e a Serra da Canastra, que marcam o início dos

Em nosso trabalho de reconstituição do traçado dos antigos caminhos coloniais, encontramos pelo menos três estradas que recebiam o nome de Picada de Goiás. A mais antiga delas, provavelmente o caminho aberto por Gomes Freire em 1736, passava pelo Registro de Sete Lagoas e pelo Porto do Espírito Santo, no Rio São Francisco e, portanto, ficava mais ao norte do que o traçado reconstituído por Vasconcelos (BARBOSA, 1998). O traçado de Vasconcelos realmente existiu, como mostra o mapa de 1788 da capitania de Minas, e a Picada Nova de Goiás tinha um traçado bem conhecido, pois foi percorrida por todos os viajantes joaninos. Os três traçados já eram mostrados no mapa de 1788. 
chapadões que se estendem até o atual Triângulo Mineiro. Provavelmente a escolha desses sítios pelos quilombolas deveu-se à dificuldade de acesso para quem vem do leste.

Descobertas de jazidas auríferas a oeste colocavam cada vez mais os mineiros em choque com os quilombolas. A sudoeste, lavras foram sendo sucessivamente descobertas nas vertentes das serras da Mantiqueira e da Canastra. Campanha (1737), Ourofino (1746) e Jacuí (1755) atraíam para suas datas os mineiros da região central e, na mesma medida, tornavam-se cada vez mais freqüentes as escaramuças entre mineradores e quilombolas na região do rio Sapucaí e no Campo Grande (BARBOSA, 1998). Em 1748, garimpeiros vindos de Paracatu, em busca de novas jazidas, foram massacrados por negros do quilombo do Queimado, no alto São Francisco. No ano seguinte, o padre Marcos Freire de Carvalho, estando à procura de ouro no Campo Grande, teve 49 membros de sua comitiva mortos num ataque quilombola. O tráfego pela Picada de Goiás também se tornara difícil para os colonos pelo mesmo motivo (VAsconcelos, 1999). A resistência dos quilombos era tão eficaz que nenhum povoado luso-brasileiro havia se estabelecido na área do sertão do Pium-i, Serra da Canastra e rio das Abelhas até 1752 (Pontes, 1978).

A guerra contra os quilombos tornou-se uma das prioridades do governo da capitania de Minas Gerais de 1746 em diante. O governador José Antônio Freire de Andrade, substituindo interinamente seu irmão Gomes Freire, organizou nessa data a entrada do capitão Antônio João de Oliveira contra o quilombo do Ambrósio, derrotando-o. Em 1757, o capitão-mor Bartolomeu Bueno do Prado enfrentou os quilombos do Indaiá, do Zundu e novamente o do Ambrósio, que ressurgira. ${ }^{8}$ Em 1758, seria a vez de Diogo Bueno da Fonseca alimpar os sertões do Pium-i, e de Antônio Francisco França a região do rio Sapucaí (VAsConcelos, 1999). A campanha assumira tal importância que o governador mudou provisoriamente a capital para São João Del Rei, de forma a ficar mais próximo do campo de operações (MeLo E SouZA, 1999).

8 Nessa expedição, surgiu a lenda, popularizada por Pedro Taques na Nobiliarquia, dos "três mil e novecentos pares de orelhas enfileiradas", que Bueno do Prado teria arrancado dos quilombolas como troféu de guerra. Diogo de Vasconcelos cita carta do governador em que o mesmo refere que o capitão-mor, após quatro meses de campanha, havia "matado 25 , prendido 20 no quilombo do Indaiá, e também prendido 49” (1999, p. 155). As patranhas eram comuns nos relatos de campanha da época.... 


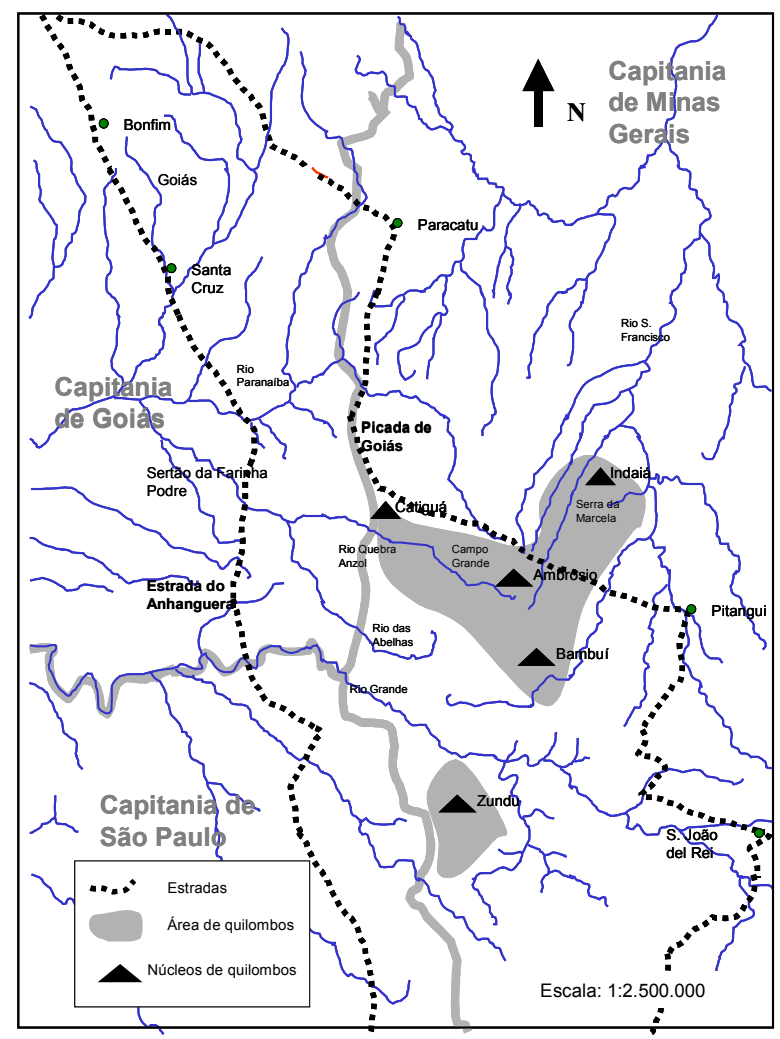

Figura 3: área dos quilombos e seus principais núcleos no oeste mineiro em 1748.

Fonte: Vasconcelos (1999).

O golpe definitivo sobre os quilombos seria dado pelo governador Luís Diogo Lobo da Silva. Nomeado capitão-general da capitania em 1763, decidiu fazer uma longa viagem pela fronteira sudoeste da capitania, para avaliar as novas descobertas auríferas e tomar informações sobre o sertão ocidental. Nessa viagem de 365 léguas, foi acompanhado pelo futuro inconfidente Cláudio Manoel da Costa (VAsconcelos, 1999).

Vivia-se então o apogeu das reformas pombalinas, dentre as quais despontava, como já visto, o projeto geopolítico de ocupação do interior da Colônia, como forma de resguardá-la dos interesses estrangeiros. A 
velha concepção de isolamento territorial das zonas mineradoras ia sendo abandonada. Mello e Souza (1999) aponta esse como um dos motivos centrais da guerra anti-quilombos. Ao mesmo tempo, já se faziam sentir os fatores de tensão demográfica na região aurífera da capitania, já analisado anteriormente.

Tendo de um lado os interesses de Estado, e de outro tendo que lidar com a tensão social, a ocupação da fronteira oeste tornara-se vital para o governo de Luís Diogo. Em 1767, o capitão-general assinou 20 cartas de sesmaria em terras além da Marcela, na Picada de Goiás (VAsCOnCelos, 1999). Entre 1764 e 1768, concedeu um total de 362 sesmarias, o que corresponde à média anual de 90,5, num evidente esforço de povoamento (Melo E SouZA, 1999).

Nesse último ano, o governador organizou aquela que seria a derradeira campanha contra os quilombolas: a expedição de Ignácio Corrêa Pamplona. Este fazendeiro, estabelecido em Pitangui e nomeado regente dos sertões do Pium-i, Bambuí, Campo Grande e Picada de Goiás, partiu em 1769 em expedição contra os quilombos, tendo também a missão de obter terras a serem distribuídas em sesmarias e fundar povoados (Melo E SouzA, 1999). O sertanista exterminou quilombos no Pium-i, Bambuí e Campo Grande, onde se encontrava o maior deles, o do Ambrósio, pela terceira vez ressurgido. Em incursões posteriores, fundou alguns povoados, erigindo capelas, entre eles Bambuí, próximo ao sítio do quilombo extinto homônimo (VASCONCELOS, 1999).

A entrada de Pamplona conta com detalhada documentação, uma Notícia Diária e Individual escrita por um de seus membros (Melo e SouzA, 1999). Nela, encontram-se inclusive mapas, mostrando o sítio e o traçado dos núcleos quilombolas. Num deles, o do Ambrósio, podemos ver (figura 4) que se situava na confluência de dois córregos. Era cercado por um valo, e depois dele havia uma linha de paliçadas e estrepes, sugerindo um amuralhamento. No núcleo, as taperas estavam dispostas de forma desalinhada em torno de um paço central. O valo ainda hoje pode ser visto (figura 5).

A partir das campanhas contra os quilombos, iniciou-se uma verdadeira vaga migratória de geralistas em direção aos sertões do oeste, da década de 1750 em diante. Esses migrantes, alguns já detentores de posses, em geral modestas, e alguns escravos, mas majoritariamente formados por roceiros pobres e negros libertos, em breve, ocupariam, com seus sítios e fazendas, as terras liberadas dos quilombos do Oeste Mineiro, apagando a maior parte dos traços de sua existência anterior. 


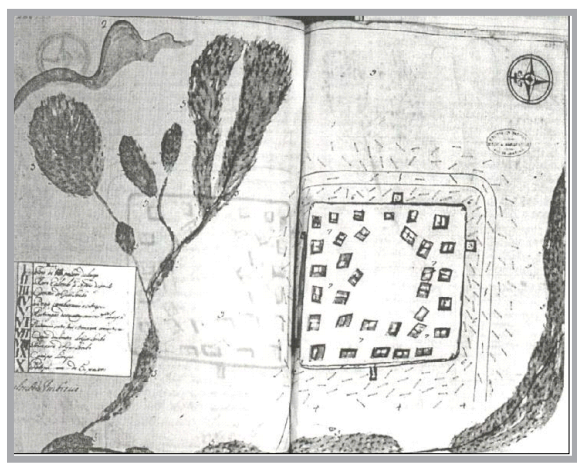

Figura 4: Quilombo do Ambrósio Fonte: Melo e Souza (1999)

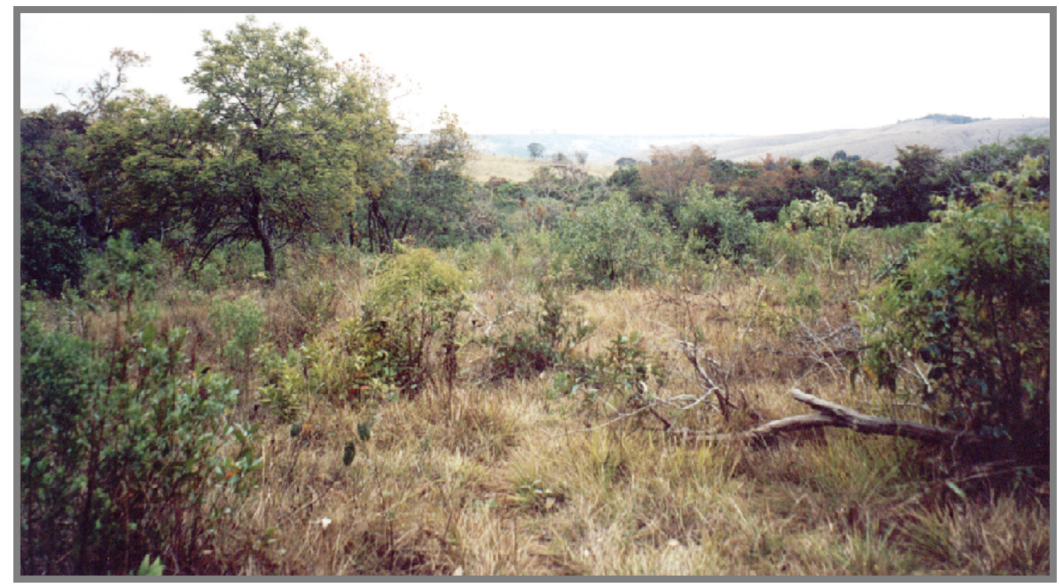

Figura 5: Sítio do Quilombo do Ambrósio (Ibiá, MG)

Fonte: foto de Lourenço, L. A. B. (2001)

\section{As picadas do Oeste e a colonização do Desemboque}

Os primeiros povoados surgidos no oeste mineiro foram ainda orientados pelas descobertas auríferas. Na mesma época em que se erradicavam os quilombos, surgiam os arraiais de Ourofino e São Pedro de Alcântara do Jacuí, na Mantiqueira, a sudoeste do atual estado de Minas, até 1755. Algum tempo depois, em 1760, formou-se o arraial de Nossa Senhora do Desterro do 
Desemboque, em torno das jazidas da cabeceira do rio das Velhas (BARBOsA, 1998). Mais ao norte, o surgimento dos povoados parece ter se dado em função da ocupação circunvizinha de pastagens para a pecuária, orientados pelas picadas Velha e Nova de Goiás (figura 6).

Existem diferenças geográficas entre o tipo de povoamento que se origina da mineração e o que surge da pecuária, apontadas por Prado Júnior (1986). As áreas mineradoras geralmente se desenvolvem sem contigüidade com outras já povoadas, pois fatores geológicos determinam a localização dos novos núcleos. As áreas de pecuária, ao contrário, vão-se espraiando por contigüidade a partir dos núcleos irradiadores, como uma atividade econômica complementar, mantendo continuidade geográfica com eles.

O caso do Oeste Mineiro, nas últimas décadas do século XVIII, é exemplar de ambos os casos. Como se pode acompanhar pela seqüência de datas na figura 6 , enquanto os arraiais ligados à pecuária lentamente se irradiavam das picadas Velha e Nova de Goiás, a extração do ouro já implantara, em paragens bem mais remotas a ocidente, dois arraiais que experimentavam intenso crescimento: Jacuí e Desemboque.

Há outra diferença, no padrão espacial de ocupação, que pudemos perceber no caso do Oeste Mineiro. A localização dos núcleos mineradores é que conformou o traçado das vias, e não o contrário. Parece lógico que, à medida que se faziam as descobertas auríferas, e que em torno delas se desenvolviam os arraiais do ouro, o intenso fluxo de mercadorias e pessoas fazia surgir os caminhos, ligando-os aos núcleos primazes ou de exportação.

No caso da ocupação pela pecuária, era o inverso que ocorria. Os caminhos funcionavam como vetores, a partir dos quais os fazendeiros iam-se instalando às margens, criando caminhos colaterais, fundando povoados. Não poderia ser diferente, pois os criadores dependiam, antes de tudo, do acesso a mercados para realizar seu excedente, na forma das boiadas comercializadas nos núcleos urbanos do leste.

Desse modo, a descoberta das jazidas do Desemboque por faiscadores vindos de Pitangui e Tamanduá, em 1760, levou ao surgimento de uma picada de Jacuí ao novo arraial, que já acusava intenso movimento em 1764 (BARBOSA, 1998). O formidável crescimento do Desemboque, entretanto, que em 1765 já contava com 195 casas, ou aproximadamente 1.300 habitantes, parece ter sido influenciado por outros fatores que não a mineração, como veremos adiante. 


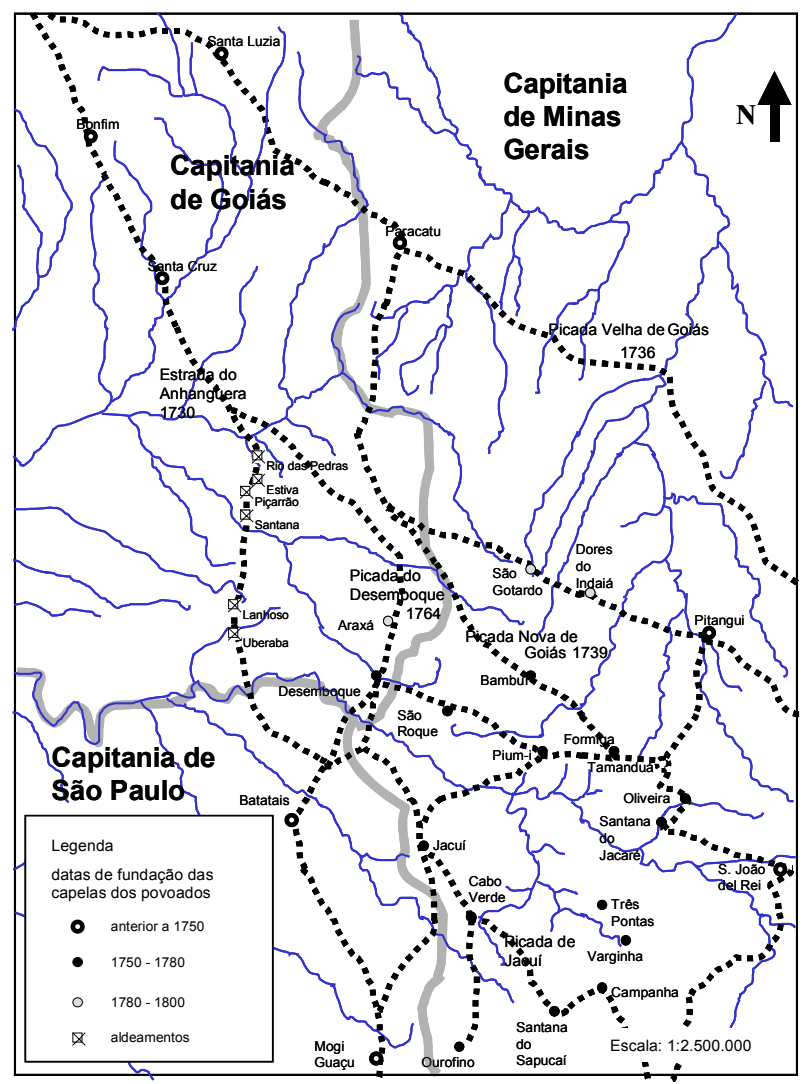

Figura 6: povoados surgidos no oeste mineiro entre 1750 e 1800, e principais picadas e caminhos. Fonte: Saint Hilaire (1975 b), Barbosa (1998) Bacelar e Brioschi (1999), Vasconcelos (1999), e Mapa da capitania de Minas Gerais (www.asminasgerais.com.br).

O padre Marcos Freire de Carvalho, do Desemboque, contrariando ordens régias, abriu uma picada partindo desse arraial até Santa Cruz, na capitania de Goiás. O bispo de Goiás reconheceu então a paróquia do Desemboque como sendo de sua jurisdição e provisionou o padre Félix José Soares, ligado a Marcos Freire, seu vigário em 1765. O fato de o novo povoado colocar-se sob autoridade goiana fez o bispo de Mariana indispor-se contra os padres do Desemboque. O 
vigário foi preso pelas autoridades eclesiais mineiras por duas ocasiões, mas o julgado do Desemboque, que passou a incluir todo o território das bacias dos rios Paranaíba, das Velhas e da margem direita do Grande, acabou se incorporando à capitania de Goiás (VAsConcelos, 1999). Devido ao litígio, ocorreram nos anos seguintes tensões — e até mesmo choques de fronteira — entre os governos das duas capitanias envolvidas (BARBOSA, 1998).

As peripécias do padre Marcos Freire e do seu vigário, padre Félix, notórios contrabandistas de ouro, foram expressivas da vontade de uma parte da população do arraial de fugir do controle do governo de Minas. A razão parece clara: quando em 1765 o governador Luís Diogo publicou uma derrama de treze arrobas, houve uma verdadeira corrida de mineiros rumo ao Desemboque para escapar dela, principalmente vindos do Tamanduá9 (VAsConcelos, 1999).

Assim, é muito provável que a rápida prosperidade do povoado tenha sido conseqüência de ele ter se transformado num centro de contrabando do ouro mineiro para fora dos limites da capitania, nas fugas do imposto do quinto e das derramas. Das 100 arrobas de ouro que, segundo Borges Sampaio (2001), saíram do Desemboque, é muito difícil saber o que realmente foi extraído ali.

A picada de Marcos Freire emendava-se à Picada do Desemboque, que seguia ao sul até Jacuí e de lá até Mogi-Guaçu, formando um desvio da Estrada do Anhanguera. Ao norte, a picada continuava pelo sítio do futuro arraial do Araxá, atravessava o rio Paranaíba e unia-se de novo à Estrada do Anhanguera em Catalão, Goiás (figura 6). Esse trajeto passou a ser usado por contrabandistas de mercadorias vindos de São Paulo. Por ele, fugiam da fiscalização do registro do rio das Velhas, na Estrada do Anhanguera, forjavam guias falsas no Desemboque e seguiam adiante (BARBOSA, 1998).

O contrabando assumiu proporções significativas, pois, em 1778, o governo de Minas interditou as passagens por sudoeste para a capitania de São Paulo, de forma a impedir que o ouro de Cabo Verde e Jacuí fosse contrabandeado, pelo desvio de Franca, para o Desemboque (BACELAR; BRIOSCHI, 1999). Em 1781, o governo de Minas instalou um posto de fronteira no alto rio das Velhas, para coibir o extravio de ouro e diamantes, mas a população e as autoridades do Desemboque destruíram-no, liderados pelo próprio comandante do regimento goiano (Pontes, 1978). Em 1789, foi a vez

$9 \quad$ Hoje Itapecerica. 
de São Paulo proibir a utilização da picada para o povoado (BARBOSA, 1998).

Desemboque contava com outros caminhos clandestinos. Havia um que o ligava a Franca, e outro que ia de Franca ao Aterrado, ${ }^{10}$ e dali ao arraial (BACELAR; BRIOSCHI, 1999). Estava ligado aos principais centros da comarca do Rio das Mortes, São João Del Rei e Tamanduá, não só pela picada de Jacuí, mas também pelo caminho mais curto do sertão do Pium-i, passando pelo arraial de mesmo nome, Formiga e Oliveira (figura 6). Situado além fronteira de Minas, mas ligado aos seus principais centros e a São Paulo e Goiás, confluência de caminhos vindos das três capitanias, o povoado beneficiou-se de uma posição privilegiada pela eqüidistância geográfica em relação a elas. Desse modo, acolhia as fugas das derramas mineiras, e ao mesmo tempo era rota de contrabando de mercadorias e ouro que trafegavam entre Goiás, Minas e São Paulo.

A hipótese de que a prosperidade do Desemboque deveu-se muito mais ao contrabando que à mineração já havia sido aventada pelo historiador uberabense Ronaldo Cunha Campos, que ainda lembrou outra evidência: o fim das derramas, no início do século XIX, coincidiu com o princípio da decadência do povoado (NABut, 1986). Nessa época, desenvolvia-se um outro núcleo vizinho, mas com uma dinâmica geográfica e econômica completamente distinta do Desemboque: a cinqüenta quilômetros ao norte, sobre a picada clandestina que levava a Santa Cruz, nascia o arraial de São Domingos do Araxá.

\section{A colonização geralista do Sertão dos Araxás}

Ao longo da Picada do Desemboque, usada pelos contrabandistas, sesmarias foram sendo concedidas desde a derrota dos quilombos do Campo Grande por Pamplona, em 1769 (BARBOSA, 1998). Esses primeiros moradores descobriram, nos chapadões situados entre as nascentes do rio Quebra-Anzol e do rio das Velhas, fontes de águas salitrosas, que passaram a usar como bebedouros para o gado.

A notícia de que, nas terras além do Campo Grande, em território goiano, havia fontes naturais de água salgada, provocou grande afluxo de colonos geralistas para a região, a partir de 1770 (VASCONCELOS, 1999). Criadores de gado, roceiros

$10 \quad$ Hoje Ibiraci. 
sem terra ou que haviam abandonado terras esgotadas, e até mesmo muitos devedores insolventes e foragidos da justiça, acorreram à região, há pouco tempo desobrigada dos quilombos (SAint Hilaire, 1975 b). Próxima ao bebedouro, foi erguida a capela de São Domingos do Araxá, ainda naquela década, transformada em paróquia em 1804 (EsCHWEGE, 1996). O arraial surgia como um núcleo que, graças aos bebedouros salitrosos, passou a polarizar a atividade de pecuária extensiva, que então avançava rapidamente pelo Oeste Mineiro.

As fazendas organizaram-se inicialmente, nas proximidades dos bebedouros. Eschwege (1996) relatou que andara quatro léguas e meia (aproximadamente $30 \mathrm{~km}$ ) do Quartel dos Ferreiros até São Pedro de Alcântara sem encontrar uma única fazenda. A partir desse arraial, as fazendas tornavamse cada vez mais comuns: três fazendas em sete léguas, até Araxá, e dali a Patrocínio, quatro fazendas em quatro léguas e meia.

Os fazendeiros araxaenses organizaram um sistema de utilização do bebedouro do Barreiro, transformado em bem público. O gado era trazido das fazendas situadas num raio de 8 a 12 léguas, uma vez por mês (figura 7). Ao chegar, a boiada era confinada nas imediações das fontes salitrosas, cercadas por um muro de pedra onde cabiam 1.500 cabeças, durante a metade do dia (Eschwege, 1996). Em 1816, havia 60 fazendeiros que se utilizavam do Barreiro, às vezes, tendo de conduzir as boiadas por vários dias desde o seu local de origem (SAINT HiLAiRe, 1975 b).

Outros bebedouros foram sendo descobertos nas proximidades. Nos pés da Serra do Salitre, os bebedouros do Salitre, Serra Negra e Marrecas deram origem, da mesma forma que em Araxá, a um arraial: Patrocínio. Na vizinhança, ao longo da Picada de Goiás, surgiram arraiais como São Pedro de Alcântara e Pouso Alegre do Carabadela, cujos criadores de gado se utilizavam dos bebedouros de Araxá e Patrocínio (SAint Hilaire, 1975 b; Eschwege, 1996).

Dessa forma, houve uma grande expansão da pecuária de corte sobre os chapadões do Alto Paranaíba e Alto Rio das Velhas, entre 1800 e 1820, orientada de um lado pela presença das fontes de água salgada e, de outro, pelas picadas, a de Goiás e a do Desemboque, que tornavam possível o acesso ao mercado do Rio de Janeiro. O aumento do fluxo de mercadorias por esses caminhos transformou os núcleos situados a jusante deles em verdadeiras bocas de sertão: Formiga e Oliveira tornaram-se importantes centros de pouso de tropeiros e boiadas, passagem obrigatória do oeste para o leste. 


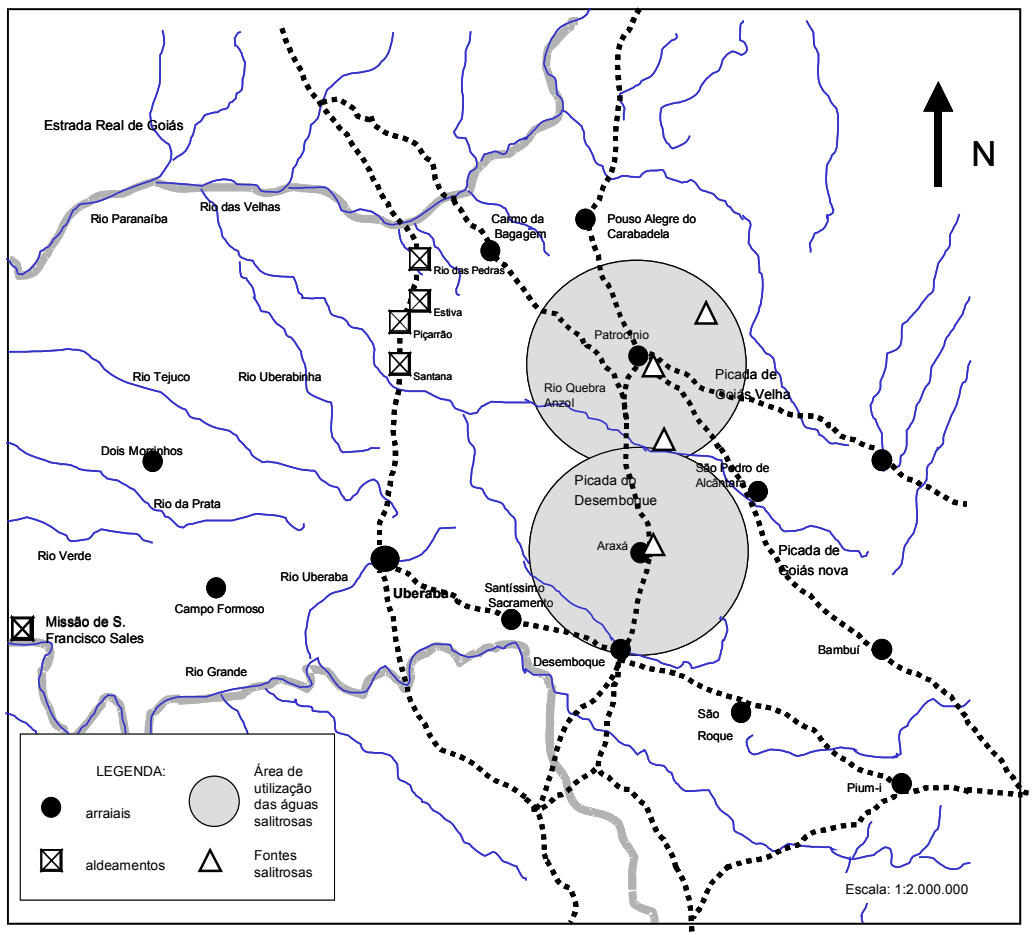

Figura 7: área de utilização dos bebedouros de Araxá e Patrocínio (1800-1820) Fonte: Saint Hilaire (1975 b), Eschwege (1996).

Os fazendeiros locais criavam os bezerros, vendidos com um ano de idade para fazendas de recria e engorda vizinhas. Quando atingiam a idade de quatro anos, eram então revendidos por estas aos compradores de São João Del Rei, que, periodicamente, percorriam a região (EsChwEGE, 1996). Esses fazendeiros araxaenses especializados na invernada tornaram-se, com o tempo, importantes compradores de gado em Goiás, principalmente das fazendas do Sul Goiano (termos de Santa Cruz e Bonfim ${ }^{11}$ ), de onde os rebanhos eram trazidos a Araxá, mantidos até a idade de abate nas fazendas próximas aos bebedouros, e então vendidos aos compradores sanjoanenses. Saint Hilaire encontrou, num pouso, pouco antes de chegar a Bonfim, mercadores araxaenses:

11 Hoje Silvânia. 
Eles percorriam as fazendas levando cobertores, chumbo para caça e outros artigos, que trocavam por bois. $\mathrm{O}$ gado assim adquirido era posto a engordar nas excelentes pastagens de sua terra e depois vendido aos mercadores da comarca de São João Del Rei, os quais [...] vão todos os anos comprar bois no distrito de Araxá (1975 a, p. 102).

Outros gêneros de menor valor, sobretudo o algodão, também tinham alguma saída para os mercados do leste, só que o ônus do transporte era dos próprios fazendeiros locais, que levavam a mercadoria em carros de boi até Barbacena. Alguns produtos agrícolas também eram comercializados em Paracatu (SAINT Hilaire, 1975 b).

Brandão (1989) refere-se à hipótese, que já havia sido levantada por Caixeta Silva (APU, 1987), de que os interesses mercantis dos criadores araxaenses foram o fator que os levou a reivindicar a separação dos julgados ${ }^{12}$ de Araxá e Desemboque e sua anexação a Minas. Parece, sem dúvida, que a condição de pecuaristas e principais intermediários na compra e revenda do gado goiano — mas contando como principal mercado São João Del Rei, em Minas — colocava-os em desvantagem. No trânsito de uma capitania a outra, incidiam dois impostos: as taxas pagas nos registros e as entradas (FURTADO, 1999). Dessa forma, as boiadas araxaenses deveriam ser vendidas a preços muito baixos aos intermediários sanjoanenses, se quisessem concorrer no mercado carioca. Pouco antes de o julgado de Araxá ser incorporado a Minas, cada rês era negociada a 7\$000 no Rio de Janeiro, e o invernista araxaense recebia apenas $4 \$ 800$ pela venda (ESCHWEGE, 1996).

Mas outros fatores também pesaram de forma decisiva. $\mathrm{Na}$ Carta Régia assinada por D. João VI, a justificativa para a transferência era a imensa distância entre Araxá e Vila Boa, o que dificultava o acesso à comarca goiana e o desembaraço de processos nos quais era necessária a ouvidoria (BARBOSA, 1998).

Graças à petição feita pelos fazendeiros araxaenses e patrocinenses, o grande território formado pelos termos dos julgados do Desemboque e de São Domingos do Araxá, que hoje corresponde ao Triângulo Mineiro, foi anexado a Minas por Carta Régia em 1816 (Eschwege, 1996). O Barão de Eschwege,

12 Um julgado era uma unidade territorial abrangida pela jurisdição de um juiz, lotado numa localidade que era a sede do julgado. O juiz poderia ser ordinário (isto é, eleito pelos moradores de posses) ou de fora (nomeado pela Ouvidoria, geralmente um jurista de carreira). Para maiores informações sobre o sistema judiciário colonial, ver Holanda (1985). 
nomeado pelo governador da capitania de Minas para determinar os limites dos novos domínios, registrou em seu diário a satisfação dos pecuaristas de Araxá e Patrocínio pela decisão régia. Na fazenda do Bom Jardim, em Patrocínio, o cronista soube que os fazendeiros haviam inclusive mobilizado representantes para que intercedessem em seu favor na Corte:

[...] pertence a um homem abastado, que estava sobremaneira empenhado em se livrar do domínio da província de Goiás e, por isso, entregou ao meu companheiro, Antônio da Costa [pecuarista araxaense], uma grande contribuição, para pagamento no Rio de Janeiro que, de acordo com o costume local, não representava apenas uma avaliação de suas despesas [do pecuarista Antônio Costa], mas também do prejuízo, com mora e juros sobre o capital que perdera [na sua estada no Rio] (EsCHWEGE, 1996, p. 114-115).

Um motivo provável para a decisão régia, favorável aos interesses araxaenses, talvez tenha sido a maior capacidade de Minas de promover a colonização do Extremo Oeste mineiro, se comparada com Goiás. Em Minas, havia um grande excedente demográfico na região central que já há mais de sessenta anos iniciara um movimento migratório para áreas de fronteira. Realmente, após a anexação dos novos territórios a Minas, foram concedidas dez sesmarias no julgado do Araxá, das quais sete apenas em 1817, no ano seguinte ao da anexação (APM, 1988). O total de sesmeiros não permite uma estimativa do total de novos fazendeiros, pois era muito comum que criadores se estabelecessem nas terras de outros como foreiros ou agregados. Segundo informação de Barbosa (1998), 50 novas famílias fixaram-se em Araxá só em 1819.

No termo da freguesia de Araxá, nesse período, foram surgindo novos arraiais, fundados pelos fazendeiros que iam se instalando na região: Carmo do Monte Carmelo ${ }^{13}$ (1816) e Santana do Pouso Alegre da Carabadela (1819). A intensidade do povoamento, nos anos seguintes à anexação, mostra que Araxá tornara-se o núcleo a partir do qual se organizava o processo de colonização do "sertão inculto" entre o rio das Velhas e o Paranaíba. Simultaneamente, mais ao sul, outro núcleo — Uberaba — exercia papel semelhante em relação

13 Hoje Monte Carmelo. 
ao sertão situado entre o rio das Velhas e o rio Grande, chamado de Sertão da Farinha Podre.

\section{A colonização geralista do Sertão da Farinha Podre}

No Desemboque, como seria de se esperar, a decisão da Coroa de anexar o julgado à capitania de Minas Gerais representou mais um revés para sua economia que, em grande parte, fundamentava-se no contrabando. O arraial perderia sua posição privilegiada de principal entreposto da tríplice fronteira, onde o tráfico clandestino de gêneros ocorria não só a partir de Minas como também de São Paulo. De 1816 em diante, entrou numa decadência irreversível.

Grande parte da população do Desemboque, a partir de então, passou a emigrar para outras regiões. A migração centrífuga transformou o arraial em cabeça de ponte para a colonização das terras mais a oeste (figura 8), antes mesmo da anexação da Farinha Podre a Minas. Dali se organizaram as entradas de colonos que, após conhecer as novas paragens, obtinham as sesmarias do governo goiano. As entradas não só levavam os colonos a conhecer as potencialidades de ocupação das áreas incultas, como, muitas vezes, eles já estabeleciam as bases da futura ocupação, ao formarem roças e ao delimitarem os terrenos para a ereção de futuras capelas.

Em 1807, uma incursão formada por seis sertanistas e seus dependentes avançou a oeste do Desemboque, retornando com boas notícias sobre a presença de terras de cultura (SILva, 1970). No mesmo ano, José Francisco de Azevedo, natural de Bambuí e estabelecido no Desemboque, tomou posse de uma sesmaria nas cabeceiras do Ribeirão Lajeado e iniciou a fundação de um arraial, com capela dedicada a Santo Antônio e São Sebastião, que passou a ser conhecido como Arraial da Capelinha ${ }^{14}$ (PONTES, 1978). Nos anos seguintes, nos arredores de Capelinha, muitos geralistas criadores de gado foram-se estabelecendo, por causa das fontes minerais salitrosas (EschwEGE, 1996). O paulista João Batista de Siqueira e o padre Cláudio José da Cunha, em 1808, penetraram até as vertentes do rio Verde, afluente do Grande, onde se apossaram de várias sesmarias (Pontes, 1978; BARBosA, 1995). Numa segunda incursão, em 1811, Siqueira chegou às férteis terras, então cobertas por matas densas, situadas entre os rios São Francisco e Piracanjuba, cerca de $170 \mathrm{~km}$ a oeste do Desemboque.

\footnotetext{
14 Hoje extinto.
} 


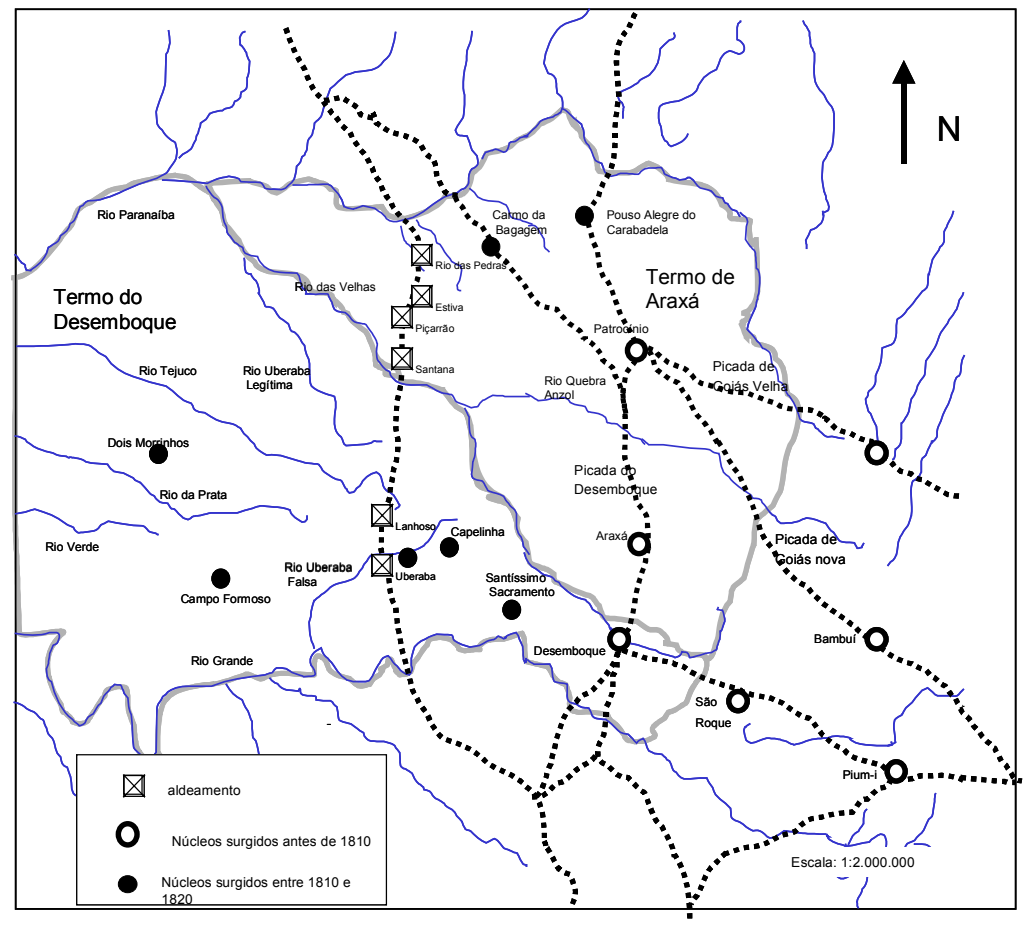

Figura 8: Sertão da Farinha Podre: núcleos surgidos até 1820 e limites dos julgados de Araxá e Desemboque.

Fonte: Barbosa (1995), Nabut (1986).

Ali demarcaram o patrimônio onde, no ano seguinte, surgiria o arraial de Nossa Senhora das Dores do Campo Formoso ${ }^{15}$ (Ferreira, 1958).

Dois anos depois, o sargento-mor Antônio Eustáquio da Silva Oliveira, natural de Casa Branca ${ }^{16}$ (arraial próximo a Vila Rica) e morador do Desemboque, organizou uma entrada com 30 sertanistas, que ultrapassou a faixa de terras dos índios em torno da Estrada do Anhanguera, e avançou até o rio Paranaíba. Na metade do percurso, próximo ao rio da Prata, escolheu o sítio para o patrimônio do futuro arraial de Nossa Senhora do Carmo dos Dois Morrinhos ${ }^{17}$ (Barbosa, 1995; Pontes, 1978).

\footnotetext{
15 Hoje Campo Florido.

16 Hoje Glaura.

17 Hoje Prata.
} 
A ocupação da fronteira pelos geralistas se fazia estruturada em parentelas. Os laços de parentesco eram importantes em todas as fases do processo, desde a organização das expedições sertanistas até o assentamento das fazendas e arraiais. Normalmente, após um pioneiro tomar posse das novas terras, voltava ao núcleo de origem para trazer sua família - esposa, filhos, dependentes e escravos, se os tivesse - para iniciar a estruturação do sítio ou fazenda. Após algum tempo, uma vez constituída a unidade produtiva, o pioneiro poderia retornar várias vezes à região de origem para buscar parentes (consangǘneos ou rituais), para que se estabelecessem nas vizinhanças. No caso em estudo, existem alguns exemplos, relativamente bem documentados, de como se estruturava uma rede de parentesco, num processo de migração e povoamento.

Em 1788, José Manoel Oliveira e Silva, geralista vindo de Vila Rica, recebeu do governo goiano a patente de Coronel Comandante do regimento de cavalaria do Desemboque e foi nomeado juiz do julgado (TeixeIra, 2001). Anos mais tarde, trouxe o irmão Joaquim, que se estabeleceu em sesmaria nos sertões recentemente desbravados a oeste (APM, 1988). Em 1807, veio de Vila Rica o terceiro irmão, Antônio Eustáquio, que, por sua influência, foi nomeado Regente dos Sertões da Farinha Podre e diretor dos índios aldeados na faixa de terras em torno da Estrada dos Goiases. Algum tempo depois, chegaria o primo, padre Hermógenes Casimiro de Araújo, que seria nomeado vigário da paróquia do Desemboque (TEIXEIRA, 2001). Essa parentela foi a fundadora de alguns dos primeiros arraiais a oeste do Desemboque, como o Santíssimo Sacramento $^{18}$ e São João Batista, ${ }^{19}$ pelo padre Hermógenes, e Dois Morrinhos ${ }^{20}$ e Farinha Podre, ${ }^{21}$ pelo sargento-mor Antônio Eustáquio (BARBOSA, 1995).

Antônio Eustáquio, o segundo irmão, organizou, em 1810, uma incursão à região que se estendia à oeste do Desemboque. Contou com 30 homens nessa expedição, quando avançou 30 léguas $(198 \mathrm{~km})$ até o rio da Prata. Ali foram "lançadas algumas posses ou sinais pelo sertão na decorrência de dois meses e feitas algumas pequenas roças" (SILVA, 1970, p. 8) Retornou ao Desemboque para "cuidar de meios para transportar-se" (p. 8), isto é, instalar-se nas novas posses, o que também fizeram os outros sertanistas que o acompanharam. Em

\footnotetext{
18 Hoje Sacramento.

19 Hoje Serra da Canastra.

20 Hoje Prata.

21 Hoje Uberaba.
} 
1812, construiu sua chácara em terras indígenas, à beira do córrego da Lage, na vizinhança da Aldeia de Uberaba, um dos aldeamentos bororos criados no século XVIII e que agora estavam sob sua direção (PONTES, 1978).

Antônio Eustáquio fez outra incursão pelos sertões do oeste em 1812, desta vez, acompanhado de seu primo, o padre Hermógenes (Silva, 1970), e de volta dela, retornou a Vila Rica, para convidar parentes a se instalarem nas novas terras (TeIXeIra, 2001). Hermógenes e os irmãos de Antônio Eustáquio, Joaquim e Domingos, afazendaram-se em sesmarias a eles concedidas nas proximidades. Só Joaquim, por exemplo, formou três fazendas: Ponte Alta, Bebedouro e Santo Inácio (Pontes, 1978).

As terras férteis em torno do arraial continuaram atraindo familias de povoadores. Os Alves Gondim, vindos de Tamanduá e Formiga; os Prata, de Tamanduá, que se apossaram das fazendas Buriti, Correias, Água Comprida, Quatis, Nunes e Alagoas, adquiridas do pioneiro João Batista de Siqueira; e entre os rios Uberaba Falsa e Tejuco, instalaram-se as parentelas dos Rodrigues da Cunha, Marquês e Pereira dos Santos (Pontes, 1978). Em 1821, João Pereira da Rocha, vindo de Paraopeba, apossou-se de uma sesmaria a ele concedida entre o rio das Velhas e o rio Uberaba Legítimo. Acompanhado de alguns camaradas, montou benfeitorias e plantou roças, voltando, em seguida, a Paraopeba para buscar a familia, escravos e protegidos. Seus treze filhos legítimos e mais dois naturais se estabeleceram em suas terras e, além disso, cedeu posses em seus domínios a outros dependentes. Algum tempo depois, José Alves de Resende, conhecido de João Pereira da Rocha e vindo também de Paraopeba, afazendou-se em terras vizinhas (Pezzuti, 1922). Pereira da Rocha vendeu parte de suas terras aos irmãos Carrejo, de quem logo se aparentou casando-se com uma prima deles.

Esses fazendeiros, muitas vezes, já traziam alguma escravaria, recebida de herança, mas a regra era que geralmente não tinham muitas posses. Por isso, desde o início, dada a dificuldade inicial de se comprar escravos, esses homens se preocupavam em ocupar suas fazendas com posseiros pobres (agregados), transformados, assim, num campesinato dependente. Grande número de pequenos e médios proprietários de terras também se estabeleceram na região, como veremos no capítulo 5 . As impressões deixadas pelos viajantes reforçam o comentário feito pelo historiador uberabense Hildebrando Pontes de que a primeira corrente migratória para os sertões da Farinha Podre "era representada por famílias pouco abastadas" (1978, p. 89). 
Ainda em 1812, um vizinho de Antônio Eustáquio, posseiro de terras indígenas, doou parte delas a outro patrimônio dedicado a Santo Antônio e São Sebastião, e iniciou nos anos seguintes a ereção da capela, nas vizinhanças da casa de Antônio Eustáquio. Esta foi autorizada por alvará de 1818, sob faculdade do padre Hermógenes, que a abençoou no mesmo ano (SAMPAIo, 2001). Surgiu então, dentro das terras aldeanas, o arraial da Farinha Podre, que, em 1820, adotaria o nome de Uberaba (Pontes, 1978).

De modo repentino, o arraial da Capelinha, o primeiro a ser fundado a oeste do Desemboque, entrou em rápida decadência e desapareceu, entre 1816 e 1817. Eschwege (1996) passou por Capelinha em 1816 e anotou que haviam sido construídas 26 casas, o que permite deduzir uma população aproximada no arraial de 156 habitantes. No ano seguinte, seus moradores se mudaram todos para a Farinha Podre, situada a uma légua mais ao sul, por razões que permanecem controversas. D'Alincourt esteve, em 1817, na Farinha Podre, e encontrou um povoado recém-construído: "a Farinha Podre é lugar de 500 pessoas de confissão [...] o principal negócio desta gente consiste de gado, e capados; e planta legumes, milho e algodão" (1975, p. 75). Borges Sampaio (2001), que viveu em Uberaba na segunda metade do século XIX e conheceu alguns dos antigos moradores da Capelinha, cita a abundância de água e as terras mais férteis como as razões da opção dos moradores e fazendeiros pela Farinha Podre. Hildebrando Pontes aponta como principal razão da transferência o "prestígio do sargento-mor Antônio Eustáquio" (1978, p. 80), que vivia nas proximidades. Edelweiss Teixeira (2001) cita o depoimento de uma neta de um morador da Capelinha, no qual relata que o povoado foi abandonado depois de um ataque dos índios caiapós, onde morreu o padre capelão. A mudança se teria dado então pela segurança oferecida pelos índios bororos da Aldeia de Uberaba, dirigidos por Antônio Eustáquio.

É muito provável que todos esses fatores tenham contribuído para que o arraial mudasse de lugar, pois a superioridade do sítio de Farinha Podre era realmente indiscutível. Situava-se ao longo da Estrada do Anhanguera, ao mesmo tempo tendo acesso a São João Del Rei e à Corte, por um caminho de 30 léguas $(198 \mathrm{~km})$, que o ligava ao Desemboque e dali a Pium-i (SAINT Hilaire, 1975 a). Além disso, contava com a presença dos quase 100 índios, que viviam nos aldeamentos de Lanhoso, Uberaba e Baixa, que, com grande probabilidade, deviam ser explorados como escravos e usados no sertanismo. 
Como no caso do Desemboque, o arraial se beneficiaria da eqüidistância de três regiões econômicas, só que agora não no contexto da economia do ouro, mas num outro, no qual o que interessava eram os fluxos e a produção de gêneros alimentícios, para um mercado interno colonial que se tornava cada vez mais importante.

O que se pode perceber é que, nos vinte primeiros anos do século XIX, ocorreu uma transferência da condição de principal núcleo do Sertão da Farinha Podre do Desemboque para Uberaba. Embora a migração a partir do Desemboque tenha seguido também a direção do julgado de Araxá, parece claro que houve interesse da elite desemboquense em criar novos núcleos e transferir-se para uma área mais promissora. $\mathrm{O}$ fundador de Uberaba e líder do processo de colonização dos sertões ocidentais fora o próprio irmão do juiz do Desemboque, e o vigário do antigo arraial fora quem conseguira o alvará de criação da freguesia de Uberaba, em 1818. Essa freguesia acabou herdando quase todo o termo do antigo julgado do Desemboque, isto é, toda a faixa de terras limitada pelos rios das Velhas, baixo Paranaíba e Grande.

Talvez o fator que, de modo mais determinante, influiu na escolha do sítio do arraial da Farinha Podre tenha sido mesmo a fertilidade dos solos da porção sudeste do Triângulo Mineiro. Trata-se de uma área onde afloramentos basálticos originaram latossolos roxos, de grande fertilidade, primitivamente cobertos por mata decídua e cerradão (ReAtTo; Correia; Spera, 1998). Ao passar por Farinha Podre, em 1819, Saint Hilaire assinalou:

As pastagens nas cercanias de Farinha Podre são tão boas que, apesar da prolongada seca que ainda se fazia sentir quando passei por lá, os campos queimados estavam cobertos por um espesso tapete verde e viçoso. Os colonos dessa região souberam tirar proveito dessa enorme vantagem. [...] tudo leva a crer que a fertilidade das terras de Farinha Podre the assegure no futuro uma grande prosperidade (1975 a, p. 151).

Eschwege também comentou da fertilidade dos solos na área do aldeamento da Baixa, ${ }^{22}$ relatando inclusive que, por causa disso, em quatro anos (isto é, de 1812 a 1816), estabeleceram-se 80 fazendas na região do sul do Sertão da

22 Hoje Baixa, distrito do município de Uberaba. 
Farinha Podre. A área de colonização, à época da passagem do engenheiro alemão, "a despeito dos assaltos, ainda a recear, dos caiapós bravios" (1996, p. 125), já avançara 20 léguas a oeste do mais meridional aldeamento de defesa da Estrada dos Goiases, tendo por limite mais extremo as margens do rio São Francisco. ${ }^{23}$ As suas informações permitem deduzir que, nessa época, a colonização já estava avançando pela região polarizada pelo arraial de Dores do Campo Formoso.

A riqueza dos solos do sul do Triângulo Mineiro (chamado então de Sertão do Novo Sul da Farinha Podre) foi também celebrizada por uma carta escrita pelo padre Leandro Rabelo Peixoto e Castro, que lá esteve em 1827, com o objetivo de fundar o colégio e seminário de Campo Belo, ${ }^{24}$ endereçada a José Teixeira de Vasconcelos, presidente da província de Minas Gerais:

Não posso deixar de dizer que na minha viagem ao sertão do Novo Sul da Farinha Podre vi talvez o mais fértil terreno da América; um campo com mais de 90 léguas povoado por geralistas e das melhores famílias, que não compreende gente ociosa ou de pouco porte, pois quase todos são fazendeiros; a produção ordinária de mais de 250 por um chega a 300 ou mais; um país o mais saudável, o mais abundante de águas, o mais próprio para criações por causa dos singulares capins sempre verdes e pelos bebedouros salitrosos [...] Em uma palavra a abundância de todos os frutos que ali produz me faz crer o que acima disse (PONTES, 1978, p. 90).

Há correlação entre a ocorrência de latossolo roxo, não só com os sítios dos primitivos arraiais que surgiram na área em questão até 1820 (Uberaba, Carmo dos Dois Morrinhos, Capelinha, Santíssimo Sacramento ${ }^{25}$ e Dores do Campo Formoso), mas também com a localização das fazendas da época. Usando inventários post mortem feitos entre 1822 e 1831 pelo Juizado de Órfãos de Uberaba, ${ }^{26}$ cujas descrições e toponímia das fazendas inventariadas foram cotejadas com cartas topográficas e uma carta de solos (SiQueIRA; Rosa, 1998), produzimos o mapa da figura 9, que mostra como as fazendas se concentravam em torno dos arraiais recém-criados, em áreas de latossolo roxo.

\footnotetext{
23. Afluente da margem direita do Rio Grande.

24 Hoje Campina Verde.

25 Hoje Sacramento.

26 Arquivo Público de Uberaba, inventários post mortem (1822 a 1831).
} 
O único arraial que, até 1830, aparecia fora dessa área de concentração, estando localizado um pouco mais ao norte, era o de Carmo dos Dois Morrinhos, paradoxalmente o primeiro a ter seu patrimônio demarcado, já na primeira incursão sertanista de Antônio Eustáquio, em 1810. Mas, apesar de o sargento-mor, desde 1811, já ter provisão da Mesa de Consciência e Ordem para a ereção da capela, não se interessou por fazê-lo até 1826, segundo o Vigário Silva, "porque a povoação do lugar, onde querem erigir a referida capela, ainda hoje é mui pouco considerável” (1970, p. 8).

Essa observação mostra que, só depois de relativamente povoada por sitiantes e fazendeiros, é que estes tomavam a iniciativa de fundar um arraial. Eles se tornavam necessários como núcleos de referência social, religiosa-cultural e mercantil da população rural. $\mathrm{O}$ arraial, que surgia com a ereção de uma capela, marcava a territorialização de um bairro rural, como veremos no capítulo 6.

Deste modo, à exceção de Dois Morrinhos, as fazendas e os arraiais concentravam-se, dos primeiros anos da colonização geralista até 1830, a sudeste do termo do julgado do Desemboque, grosso modo em um quadrilátero limitado pelos paralelos $19^{\circ} 27^{\prime}$ e $20^{\circ} \mathrm{S}$ e os meridianos $48^{\circ} 52^{\prime}$ e $47^{\circ} 7^{\prime} \mathrm{O}$, em área de matas e cerradões e de ocorrência de latossolos roxos eutróficos.

Percebe-se, contudo, que, apesar de as fazendas se concentrarem nessa área, estavam praticamente ausentes no vale do rio Grande. Realmente, dos 167 inventários do Juizado de Órfãos de Uberaba produzidos entre 1822 e 1861, por nós revisados, apenas um deles cita o rio Grande como divisa de fazenda. ${ }^{27}$ A explicação dessa ausência é, possivelmente, epidemiológica. A endemicidade da malária, ${ }^{28}$ nas matas daquele vale, foi aludida por Saint Hilaire (1975 a) e Eschwege (1996) como a razão da transferência do Registro da Fazenda Real das margens do rio Grande, divisa entre as capitanias de Minas e São Paulo, para o rio das Velhas. D’Alincourt (1975) descreveu a área de inundação do rio como "sazonática" ${ }^{29}$ e, seguindo no sentido sul-norte após cruzá-lo, só foi encontrar o primeiro morador nas proximidades do Registro da Posse, próximo ao Quartel das Toldas, destacamento militar a pouca distância do arraial da Farinha Podre. Saint

27 Arquivo Público de Uberaba, inventário de Antônio Leal Alemão, 04/09/1832, maço N6.

28 Doença trazida da África pelo tráfico negreiro e que rapidadamente se alastrou pelas regiões tropicais e subtropicais da América.

29 Causadora das sazões ou malária. 


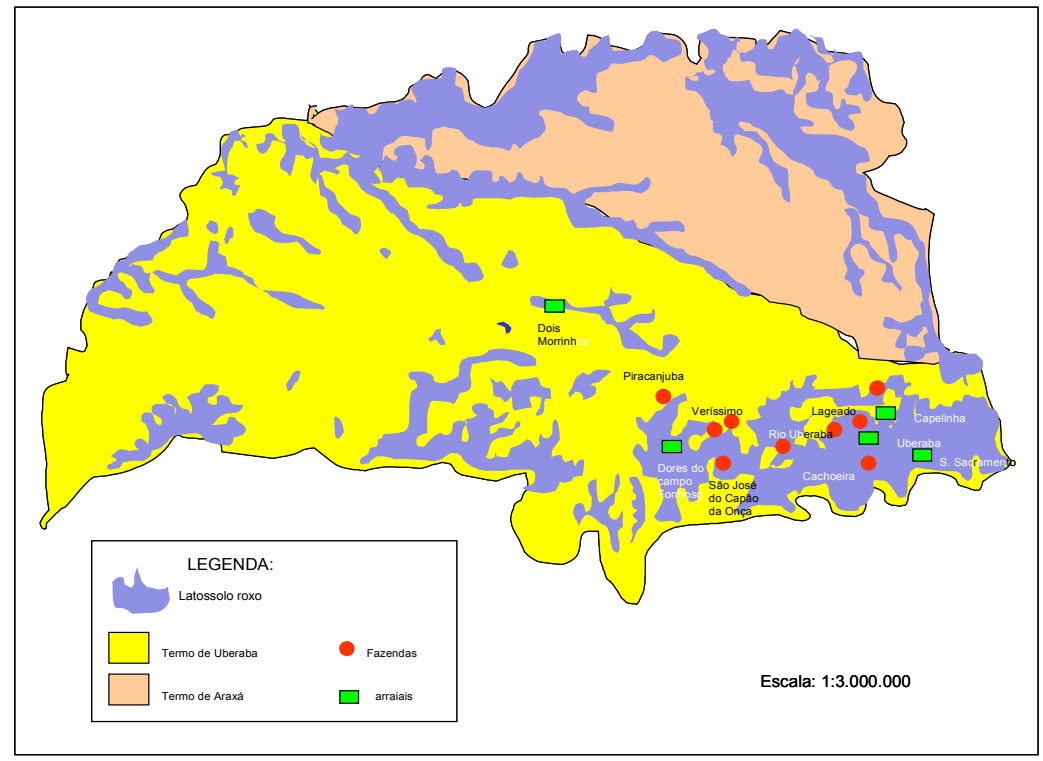

Figura 9: Termo de Uberaba (1822-1831): solos e localização das fazendas inventariadas no Juizado de Órfãos da Vila de Uberaba.

Fonte: APU, inventários post mortem (1822 a 1831), Siqueira e Rosa (1998).

Hilaire, depois de passar pelo Quartel das Toldas em direção ao rio Grande, seguindo no sentido contrário ao de D'Alincourt, dois anos depois dele, não encontrou sitiantes, a não ser um casebre onde morava uma família que recebia o pedágio da travessia. Desconhecendo, obviamente, que o mosquito anofelino era o vetor da doença, escreveu:

Já me referi à insalubridade do Rio Grande. As terras pantanosas que o margeiam ficam inteiramente recobertas pelas águas na estação das chuvas. Depois o terreno vai secando paulatinamente. E nos meses de abril, maio e junho começa a exalar vapores pestilenciais que causam febres malignas e febres intermitentes. O homem que recebia o pedágio em nome da família Anhanguera e morava num casebre na margem esquerda do rio disse-me que se estabelecera ali havia quinze anos e ficara doente dez vezes. Naquele ano, particularmente, todas as pessoas da casa tinham adoecido (1975 a, p. 154). 
Com o desmatamento das margens do rio, ao longo do século XIX, e a extinção da fauna que funcionava como reservatório natural do Plasmodium sp., a endemia foi sendo aos poucos erradicada, permitindo o povoamento mais efetivo do vale. No tempo de Borges Sampaio (2001), no final daquele século, ocorriam ainda casos esporádicos de malária.

O crescimento da população nas terras recém-conquistadas foi muito rápido para os padrões da época. Eschwege (1996), em 1816, estimou a população do julgado do Desemboque (que incluía então todo o Sertão da Farinha Podre) em 3.945 habitantes. A totalização do recenseamento de Silva Pinto, de 1821, somava, no termo do julgado, 7.655 habitantes (Cunha Matos, 1981), número que se aproxima do que calculamos com base no Mappa Estatístico da Secretaria de Estado dos Negócios da Justiça, de 1825, que somava 856 fogos nos arraiais e 290 fogos rurais, permitindo estimar algo em torno de 6.876 habitantes (RAPM, 1897). De qualquer forma, apesar da inexatidão das estatísticas oitocentistas, particularmente em regiões de fronteira, esses números mostram um crescimento demográfico não menor que $60 \%$ em nove anos.

Contudo, ainda não analisamos de perto essa intensa migração de geralistas, ocorrida na primeira metade do século XIX, e que foi o grande motor da transformação de uma região indígena numa região de unidades rurais agropastoris, integrada ao mercado interno da Colônia e do Império. Resta considerar dois aspectos: os fatores de repulsão e atração migracional dos roceiros e criadores geralistas; e o confronto entre estes e os outros grupos humanos que já se encontravam na região. Estes consistiam dos últimos remanescentes dos índios caiapós, na confluência dos rios Paranaíba e Grande, e dos índios bororos, parecis e chacriabás, aldeados pelo governo goiano ao longo da Estrada do Anhanguera.

\section{Fatores demográficos de repulsão e atração migracional}

Em 1816, o Barão de Eschwege fez uma viagem aos julgados do Araxá e do Desemboque, designado pelo governo mineiro para iniciar a demarcação, e fazer uma estimativa demográfica e econômica das potencialidades daqueles territórios, então incorporados à capitania de Minas Gerais. A caminho daquela região, entre os arraiais de Formiga e Bambuí, encontrou uma grande 
caravana de emigrantes "que se dirigiam para as regiões incultas do Araxá e Desemboque" (1996, p. 86).

O engenheiro alemão fez uma viva descrição desses migrantes, flagrados em pleno trânsito para o vale do rio Paranaíba, onde iriam se estabelecer:

Em dois carros de bois, transportavam algumas caixas e panelas e muitas crianças, pretas, brancas e mulatas. Dez mulas transportavam os mantimentos e outros objetos. Escravos de ambos os sexos tocavam diversos animais, inclusive vacas e cabras. Os membros do grupo, a cavalo, acompanhavam a tropa, seguidos dos cães de caça e perdigueiros (1996, p. 87).

O cronista perguntou ao chefe da família as razões do abandono da terra natal, Congonhas do Campo, na região aurífera. Este lhe respondeu que havia abandonado suas propriedades "sem mesmo tentar vendê-las" (p. 87), pois as terras estavam cansadas, tendo perdido metade de sua fertilidade em um ano de cultivo.

Essa preciosa cena, legada por Eschwege, ajuda a esclarecer alguns elementos do movimento migratório geralista que povoou o Triângulo Mineiro, nas primeiras décadas do século XIX. Por ela, sabemos que parte desses migrantes chegou à região já com algumas posses, na forma de escravos e rebanhos, as principais formas de riqueza de então. Sabemos também que se tratava de uma migração familiar, isto é, núcleos familiares deslocavam-se por inteiro para as regiões de fronteira, com o objetivo de reproduzir unidades agropastoris sustentadas pelo trabalho de todos os seus membros, muitas vezes, complementado pelo trabalho escravo.

O caráter familiar diferenciava-a de outras migrações, tipicamente masculinas, como a imigração portuguesa para os núcleos mercantis mineiros, na época em estudo. Esse fluxo foi estudado por Júnia Ferreira Furtado (1999), usando inventários post mortem de Vila Rica e do Serro do Frio, na segunda metade do século XVIII. A autora assim caracterizou o perfil do comerciante que se estabelecia naqueles núcleos:

Em geral, provinham do Norte português, especialmente Minho e Douro. Eram, em sua maioria, solteiros, sem grandes vínculos familiares e deixavam numerosa prole bastarda, geralmente com negras, muitas delas alforriadas em testamento (1999, p. 275). 
As migrações coloniais para as regiões de fronteira agrária tinham um perfil muito distinto. Castro Faria (1998), estudando a região de Campos dos Goitacases dos séculos XVIII e XIX, concluiu que a mobilidade espacial era muito grande, em todas as camadas da sociedade. Normalmente, os libertos somente emigravam após constituir família, pois, segundo a autora:

Em zonas agrárias, a presença da família, pelo menos a constituída pelo casal, era condição básica para o estabelecimento de unidades domésticas de produção, em particular para os mais pobres. A necessidade de uma maior estabilidade levava ao casamento legal. Em 147 inventários post mortem de proprietários rurais, do século XVIII, dos Campos dos Goitacases, pôde-se verificar que $96 \%$ eram casados (1998, p. 155).

Em seguida, a autora aponta a razão de uma taxa de casamentos tão alta, em regiões rurais:

A recorrência das taxas torna clara a necessidade de constituir e manter família em áreas rurais, tanto para os ricos quanto para os pobres, em contraste com as áreas urbanas onde as atividades econômicas não pressupunham, a princípio, a família como base de produção (1998, p. 155).

Esse parece ser o caso da população do Sertão da Farinha Podre nos primeiros anos do século XIX. Em nossa região de estudo, nos 167 inventários post mortem analisados, produzidos entre 1822 e 1861, no termo da freguesia (depois Vila) de Uberaba, encontramos 21 testamentos, nos quais se revela a origem do testador. Verificou-se que, em cem por cento dos casos, eles haviam nascido fora do termo, revelando o caráter adventício da população. Dos inventariados, 165 eram casados e apenas dois solteiros, o que corresponde a uma taxa de nupcialidade de 98\%, próxima à encontrada por Castro Faria em Campos.

Usando os títulos de herdeiros dos inventários, ${ }^{30}$ que trazem sempre o nome dos herdeiros, sua condição — casado, solteiro ou viúvo — e geralmente sua idade, procuramos deduzir a taxa e a idade média de nupcialidade da população

30 Para uma revisão dos métodos de construção de fichas de família em Demografia Histórica, ver Marcílio (1977). 
do termo de Uberaba, entre 1822 e 1861. Construímos, para isso, o gráfico 1. Percebe-se que apenas duas, de cada dez mulheres, permanecia solteira após os 25 anos. Entre os homens, a taxa de nupcialidade era ainda maior: depois dos 35 anos, menos de um homem, de cada dez, permanecia solteiro. As mulheres se casavam entre os 15 e os 20 anos, e a partir dessa idade diminuíam muito as suas chances de matrimônio, mantendo-se constantes as taxas de celibato feminino após os 20 anos. Os homens, por sua vez, casavam-se em idades que variavam dos 20 aos 35 anos. Esse perfil diferia bastante dos imigrantes portugueses do sexo masculino nos núcleos urbanos, os quais mantinham taxas de celibato, quando de suas mortes, de até 76\% (FurTAdo, 1999).

A taxa de nupcialidade relativamente maior dos homens reflete um fenômeno típico de populações do tipo pré-malthusiano, presente na maioria

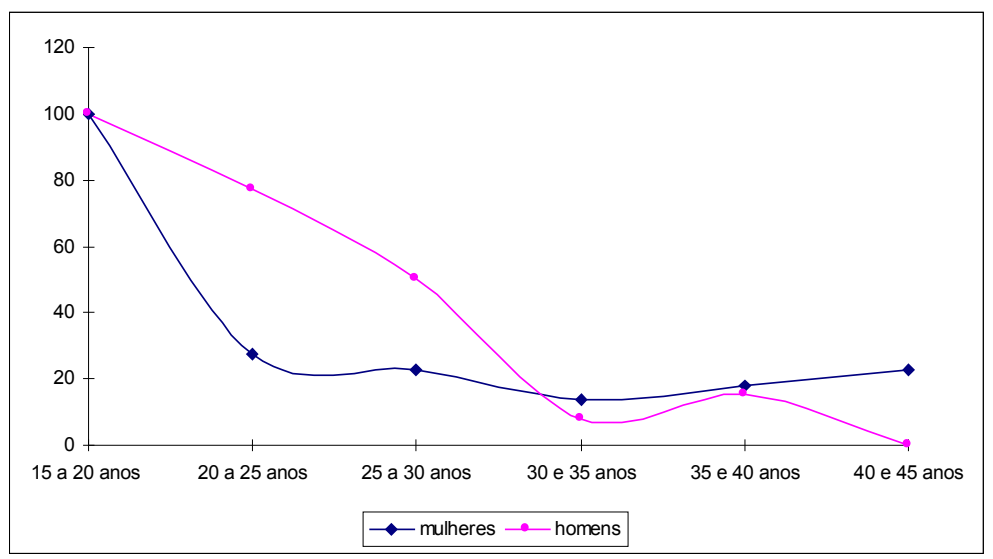

Gráfico 1: mulheres e homens solteiros em relação aos casados, em função da idade (15 a 20 anos $=100)$, no termo de Uberaba (1822-1861)

Fonte: APU, série de 167 inventários do Juizado de Órfãos de Uberaba (1822-1861).

dos estudos relativos a populações rurais coloniais: ${ }^{31}$ a maior mortalidade masculina, reduzindo a razão de gênero — número de homens para cada 100 mulheres - a números menores que 100. Usando os dados censitários

31 Ver, por exemplo, Marcílio (2000). 
coligidos por Luiz Maria Pinto em 1821 (Cunha Matos, 1981), referentes ao Desemboque (que incluía o termo da freguesia de Uberaba), verifica-se que, naquela data, havia 3.176 homens e 3.282 mulheres livres no julgado, o que perfazia uma razão de gênero igual a 96,77, valor próximo ao encontrado por Marcílio (2000) — 91,55 — para a província de São Paulo em 1828. ${ }^{32}$ Tais números, é importante ressalvar, referem-se à população livre. Entre a população escrava, as razões de gênero eram sempre maiores que 100, refletindo o efeito do tráfico, como veremos no capítulo 5.

A vaga geralista no Triângulo Mineiro teve, portanto, o caráter de uma migração familiar: só após constituir família é que roceiros e criadores decidiam deslocar-se para essa região de fronteira. Que fatores — resta saber - levavam essas pessoas a tomarem tal decisão? Já abordamos em parte esta questão páginas atrás, ao discutirmos os efeitos produzidos pela mineração aurífera e pelo crescimento demográfico sobre as terras de cultura, na região central de Minas Gerais. Vimos que esses fatores levaram ao esgotamento da fertilidade natural dos solos, o que empurrou parte da população das comarcas de Ouro Preto, Mariana e Sabará para as comarcas do Rio das Mortes, Serro do Frio e Paracatu, da qual faziam parte os julgados do Desemboque e Araxá.

A cena descrita por Eschwege ilustrou, de forma lapidar, que também a região em estudo recebeu famílias que migraram por causa desses fatores. Com efeito, em nossa série de 21 testamentos do Juizado de Órfãos de Uberaba, escritos entre 1822 e 1861, mapeamos a origem declarada dos testadores (figura 10). Observa-se que a maioria vinha de um polígono formado por Vila Rica, Conceição de Mato Dentro, Prados e Tamanduá, regiões mineradoras ocupadas no século XVIII, comprovando que parte da diáspora da zona aurífera também se dirigiu para o Triângulo Mineiro, nos primeiros anos do século XIX. Porém, o mesmo mapa mostra que uma fração dos migrantes também veio de zonas agropastoris prósperas, como Formiga, Baependi e Curral Del Rei. ${ }^{33}$ Seria um erro, portanto, imputar a uma suposta "decadência" da zona

\footnotetext{
32 Acreditamos que não só a aritmética da demografia, mas também fatores culturais, estão por trás das taxas relativamente maiores de celibato feminino. Saint Hilaire (1975 b) e Eschwege (1996) referiram-se ao costume de as famílias imporem o celibato a algumas filhas, para que cuidassem da velhice dos pais.

33 Hoje o sítio da capital planejada de Minas, Belo Horizonte.
} 
aurífera o único fator de repulsão migracional dos geralistas que chegaram ao Triângulo Mineiro e outras regiões.

Nossa hipótese é que a migração geralista foi o resultado natural de pressões demográficas exercidas sobre regiões agropastoris, onde a agricultura e a pecuária eram praticadas sob determinadas condições técnicas, que

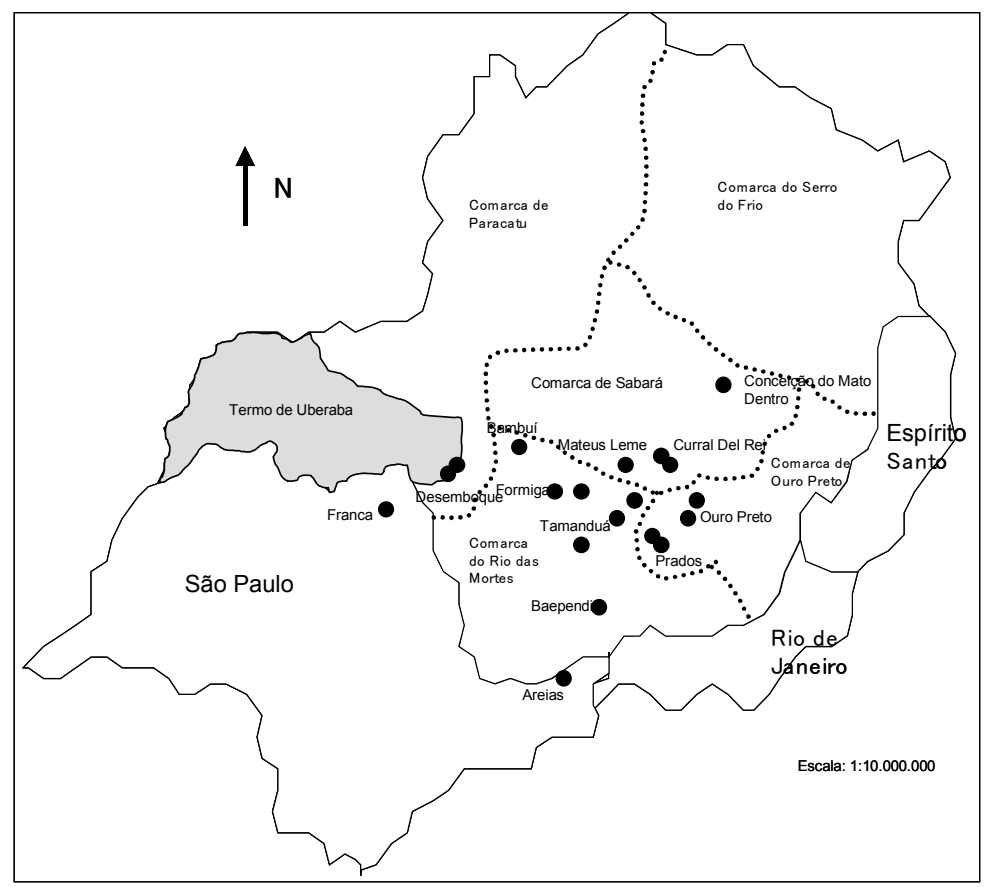

Figura 10: naturalidade dos testadores da freguesia de Uberaba (1822-1861)

Fonte: Arquivo Público de Uberaba, série de 21 testamentos do Juizado de Órfãos de Uberaba (1822-1861).

impunham limites à densidade demográfica, e obrigavam à mobilidade horizontal. Essa hipótese não é inteiramente nova, embora o seja para o caso mineiro. Marcílio (2000) e seus orientandos (BACELAR, 2001) há muito já vêm demonstrando a importância da dimensão demográfica e ambiental no estudo das migrações coloniais, especialmente aquelas ocorridas na capitania de São Paulo, entre os séculos XVIII e XIX. 
Contando com um singular corpo documental — as listas anuais e nominativas de todos os habitantes de cada uma das vilas da capitania de São Paulo do século XVIII — que, lamentavelmente, não foi produzido, na mesma época, em outras regiões do Brasil, os autores vêm estudando as relações entre população, recursos e ambiente em São Paulo colonial. Marcílio, ao estudar a estrutura familiar e a mobilidade espacial no meio rural setecentista de São Paulo, concluiu, pela existência de relações entre o padrão de família nuclear — formada por pai, mãe e filhos solteiros — o sistema de pousio florestal ou arbustivo e a mobilidade espacial:

A economia era de autoconsumo com escasso excedente para troca; a família do roceiro, base econômica, social e cultural do sistema de agricultura de repouso florestal, era, no entanto, predominantemente pequena, resumindo-se na célula conjugal e nos poucos filhos solteiros sobreviventes. $\mathrm{O}$ patrimônio quase nulo desses grupos domésticos rústicos — reduzidos quase que apenas a enxada e machado, alguma arma de fogo e um tosco rancho de sapé — estava associado justamente aos contínuos deslocamentos do grupo para novas parcelas desbravadas mais adiante na mata virgem (2000, p. 161).

O sistema de pousio florestal — vinte anos, em média, de descanso após o plantio, com reconstituição da mata secundária — exigia uma larga área útil para grupos familiares relativamente pequenos, o que restringia as densidades demográficas. Aumentos de população podem levar à adoção do pousio arbustivo - pousios mais curtos, de cinco a sete anos, com reconstituição de vegetação secundária do tipo herbáceo-arbustivo ou capoeira — - que leva a uma redução da produtividade por unidade de área. Aumentos ainda maiores de população, mantendo-se as mesmas técnicas rústicas de cultivo, poderiam levar a reduções ainda maiores na produtividade, rompendo o equilibrio entre população e produção de alimentos e gerando fomes. Contudo, dispondo-se de áreas de fronteira com solos de mata virgem, as migrações impediriam aquela situação limite, como foi o caso em quase todo o período colonial.

A mobilidade espacial, nesse caso, seria decorrência estrutural do crescimento demográfico, numa população vivendo sob um sistema rústico de agricultura, e que contava com áreas de fronteira. O crescimento da população, por sua vez, seria decorrência do próprio caráter familiar da unidade rural. 
Usando uma lógica que lembra a do equilíbrio trabalho-consumo, de Chayanov (1986), a autora comenta:

Qualquer aumento do grupo doméstico, por inclusão de mais pessoas, embora significasse aumento de mão-de-obra, representava, sobretudo, necessidade de extensão da área cultivada para atender as novas bocas. O equilíbrio entre população e produção para o consumo se mantinha quando a família se resumia no casal e nos filhos, e ele só era quebrado quando a família se tornava incompleta, ou no caso de algum de seus membros ativos ficar incapacitado para o trabalho (MArcílio, 2000, p. 161).

Dito de outra forma, tratava-se de um ciclo de retro-alimentação positiva, no qual a prole numerosa, importante para constituir o núcleo familiar de trabalho por garantir ganhos marginais, impunha, por sua vez, uma intensificação dos cultivos e/ou um aumento da área cultivada. Quando os filhos se casavam, constituíam então eles próprios novos núcleos familiares, destacando-se do núcleo paterno e assentando-se nos arredores ou em áreas distantes, reiniciando o ciclo noutra área.

A autora explica, dessa maneira, a tendência a se constituírem núcleos familiares pouco numerosos, contrariando a idéia, até algum tempo consensual entre historiadores, da família extensa - três ou mais gerações vivendo sob o mesmo teto - como o padrão no período colonial. Na verdade, a necessidade da mobilidade, tornada imperativa pelo próprio sistema tradicional de cultivo, impunha o desmembramento de novos grupos familiares, assim que os filhos se casassem.

Uma dinâmica semelhante ocorria nas comarcas mineiras de colonização mais antiga, como a de Ouro Preto, de Sabará e do Rio das Mortes. Na região do rio Paraopeba, Eschwege (1996) referiu-se ao sistema de pousio arbustivo como o então adotado pelos agricultores locais. Saint Hilaire também descreve o mesmo sistema, afirmando que era adotado principalmente nas regiões próximas a Vila Rica:

Nos pontos da província de Minas que se avizinham de sua capital as capoeiras que substituíram as florestas virgens são geralmente cortadas ao cabo de cinco, seis ou sete anos. Depois de se desenvolverem livremente durante vinte anos 
essas matas, então chamadas de capoeirões, adquirem o mesmo vigor das florestas primitivas (SAint Hilaire, 1975 b, p. 136).

Nos arredores de Itambé, o esgotamento dos solos como resultado do encurtamento do pousio foi relatado ao cronista por um fazendeiro. De início, as terras eram "grandemente produtivas". Ao final de alguns anos, contudo, “o milho não rende mais [...] do que 100 por 1" (SAINT Hilaire, 1974, p. 56).

Na região do Oeste Mineiro, porém, os roceiros preferiam as áreas de mata virgem para plantio, devido à abundância destas. Em Pium-i, os agricultores "derrubam as matas dos arredores que se prestam a todo tipo de cultura" (SAINT Hilaire, 1975 b, p. 96). Em Araxá, "como em todos os lugares, só se planta nos capões, ficando os campos reservados exclusivamente aos rebanhos” (p. 130).

O esgotamento das terras das regiões de origem foi a razão alegada aos viajantes joaninos por todos os geralistas que haviam se estabelecido no Triângulo Mineiro. Em Araxá, Saint Hilaire encontrou imigrantes vindos de Sabará (1975 b), e em Farinha Podre, vindos de Formiga e Oliveira (1975 a). Eschwege deparou-se, nas proximidades do rio Grande, com um geralista de Congonhas do Campo, "onde deixara casa e uma grande fazenda, já inteiramente desprovida de matas” (1996, p. 131).

Pelo relato desses cronistas, percebe-se que os sitiantes se estabeleciam quase sempre em unidades familiares simples, isto é, formadas pelo casal e seus filhos. À beira do rio Tejuco, no Sertão da Farinha Podre, Eschwege (1996) encontrou uma fazenda habitada apenas por um casal com um filho pequeno. Nas proximidades do arraial da Capelinha, encontrou dois jovens recémcasados, ainda sem filhos. Saint Hilaire, na Serra da Canastra, perguntou a um homem que lá havia se estabelecido "como podia ele viver em lugar tão solitário. Respondeu-me que gostava do sossego e além do mais não vivia sozinho, pois tinha mulher e filhos" (1975 b, p. 102).

Famílias simples, conjugais, foi o que encontramos também no estudo dos inventários oitocentistas de Uberaba. Os títulos de herdeiros, presentes nos inventários, constam sempre o nome dos filhos, condição (casado, solteiro ou viúvo), idade e local de moradia, se com o inventariante ou noutro lugar. Por meio deles, portanto, foi possível reconstituir a estrutura da maioria das famílias dos inventariados. Percebemos que raramente os filhos casados permaneciam morando com os pais, porém freqüentemente se assentavam nas imediações. Por 
exemplo, no inventário de Lauriana Teresa dos Santos, ${ }^{34}$ seus filhos Deodoro, José, João e Jerônimo, respectivamente com 20, 18, 16 e 15 anos, todos solteiros, moravam "em companhia de seu pai”, o viúvo Manuel Antônio da Silveira. Já os filhos casados Maria, Luciana e Custódio residiam na mesma fazenda, mas em outros sítios. Os filhos Francisco e Pedro, solteiros, mas um pouco mais velhos — respectivamente com 25 e 30 anos — residiam também em habitações separadas: um na mesma fazenda, e o outro em Dores do Campo Formoso.

Quantificando-se os dados dos títulos de herdeiros, pudemos ter uma idéia diacrônica da dinâmica demográfica familiar. O gráfico 2 foi construído calculando-se o número médio de membros, em função da idade da família. ${ }^{35}$ Nele se pode perceber que as famílias de 20 a 30 anos alcançavam o número máximo de membros, em média dez pessoas, que decaía logo depois, com o casamento dos filhos, a uma média de cinco pessoas. Trata-se do que Marcílio (2000) chamou de ciclo vital das famílias do meio rural tradicional brasileiro, do período colonial: uma história de vida que consistia na constituição de uma família conjugal num novo fogo, o nascimento de filhos, sua adolescência quando a família atingia 20 anos de idade e vivia o seu apogeu produtivo - e o casamento dos filhos, com o desmembramento da família em novas unidades conjugais e a permanência apenas dos pais idosos, com um ou outro filho celibatário, quando a família atingia a idade superior a 30 anos.

Esse padrão — novas famílias desmembradas das parentais, mas fixandose nas cercanias destas — também foi observado por Castro Faria (1998) em seu estudo dos inventários post mortem da região de Campos dos Goitacases, do século XVIII. Os casais novos se estabeleciam, segundo a autora, em novos sítios em terras dos pais ou sogros. Saint Hilaire também observou o mesmo, em sua viagem pela região em estudo, em 1819. Em Serra da Canastra, "os escassos habitantes dos arredores [...] parecem todos aparentados uns com os outros" (1975 b, p. 105). No sítio do Pari, próximo a Bonfim de Goiás, "os numerosos moradores [...] [são] todos parentes uns dos outros" (1975 a, p. 109).

Acreditamos, portanto, que os fatores que levavam à migração e dispersão da população rural, analisados por Marcílio (2000) — tensão demográfica crescente sobre solos com diminuição do tempo de pousio,

\footnotetext{
34 APU, inventário de Lauriana Teresa dos Santos (14/08/1838), maço N7.

35 Estimamos a idade da família adicionando-se um ano à idade do filho mais velho.
} 


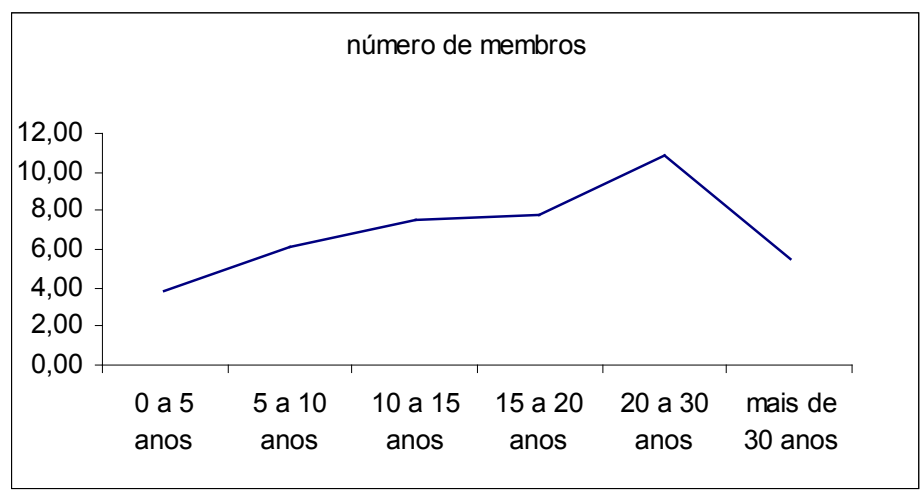

Gráfico 2: número de membros em função da idade das famílias, no termo de Uberaba , entre 1822 e 1861.

Fonte: 174 inventários do Juizado de Órfãos de Uberaba (1822-1861).

demanda por novas áreas cultiváveis — também estavam presentes em Minas Gerais, tanto na emigração a partir das áreas de colonização setecentista (região aurífera e comarca do Rio das Mortes) para o Sertão da Farinha Podre, quanto nos deslocamentos ocorridos no interior desta última região. Em decorrência disso, o padrão era de uma permanente mobilidade espacial da população.

Contudo, tal processo migratório não se fazia a esmo, mas estruturado em parentelas, isto é, grupos de famílias nucleares unidas entre si por laços de parentesco consangüíneo ou ritual, e vivendo em habitações próximas (LEWIN, 1987). As pessoas procuravam instalar-se em áreas onde pudessem contar com redes de solidariedade vicinal, fundamentais à dinâmica da economia e da sociedade camponesas. Tais redes eram mais confiáveis - e se estruturavam mais rapidamente — quando formadas por parentes.

Outro aspecto importante a ser notado no gráfico 2 é a média de filhos das famílias do julgado de Uberaba, na primeira metade do século XIX. Como se verá no capítulo seguinte, um grande número de filhos era desejável pela familia rural, como forma de ampliar a força de trabalho familiar. No apogeu de seu ciclo vital, as famílias contavam em média com oito filhos sobreviventes, decaindo, em seguida, com o casamento deles. A fecundidade dos casais devia ser muito maior, pois tratava-se de uma sociedade em que as mulheres se 
casavam jovens e não havia nenhum tipo de controle de natalidade. Porém, a elevada taxa de mortalidade — principalmente infantil — impedia que as proles fossem ainda mais numerosas.

Pudemos estimar as taxas de mortalidade infantil e juvenil calculando o lapso médio entre um filho e outro, em função da idade destes. A taxa de fecundidade era muita elevada, pois o intervalo médio entre os filhos mais jovens era de apenas um ano. $\grave{A}$ medida que aumentava a idade dos filhos, aumentava proporcionalmente o intervalo entre eles (gráfico 3). Percebe-se que há uma forte inclinação da curva de zero até cinco anos de idade, quando o intervalo médio entre filhos saltava de 1 para 2,3 anos, o que se devia à elevada mortalidade infantil. Dos cinco até os vinte anos, a curva se mantinha quase horizontalizada, para novamente sofrer inclinação ascendente após essa idade, por causa da mortalidade juvenil. Esta provavelmente estava ligada a fatores ambientais, como o trabalho ou a violência. Tratava-se, portanto, de uma população de tipo pré-malthusiano, isto é, sem nenhum controle sobre a natalidade ou a mortalidade (MARcílio, 2000), mas que, por causa da alta natalidade, tinha crescimento vegetativo positivo.

É necessário lembrar que, ao usar esse tipo de fonte, podemos apenas fazer inferências qualitativas sobre as tendências demográficas na região em estudo. Tais inferências, para serem confirmadas, necessitariam de estudos usando fontes mais adequadas, como, por exemplo, os registros paroquiais.

\section{Fatores geopolíticos na migração geralista}

Vimos, no segundo capítulo, que, do período pombalino em diante, a Coroa portuguesa mudara suas estratégias relativas ao território colonial. As antigas regiões "proibidas", que rodeavam as zonas auríferas e diamantíferas, onde era vedada a colonização e a abertura de estradas, desapareceriam em nome de uma nova orientação geopolítica. No entendimento do Marquês de Pombal e de seu círculo de intelectuais iluministas, o território e a população da colônia americana passaram a ter um novo significado. Importava, assim, criar um mercado que pudesse estimular as manufaturas portuguesas e, em especial, criar uma economia complementarà da metrópole, inclusive com algumas unidades industriais, como as forjas siderúrgicas de São Paulo e Minas (NovAIs, 


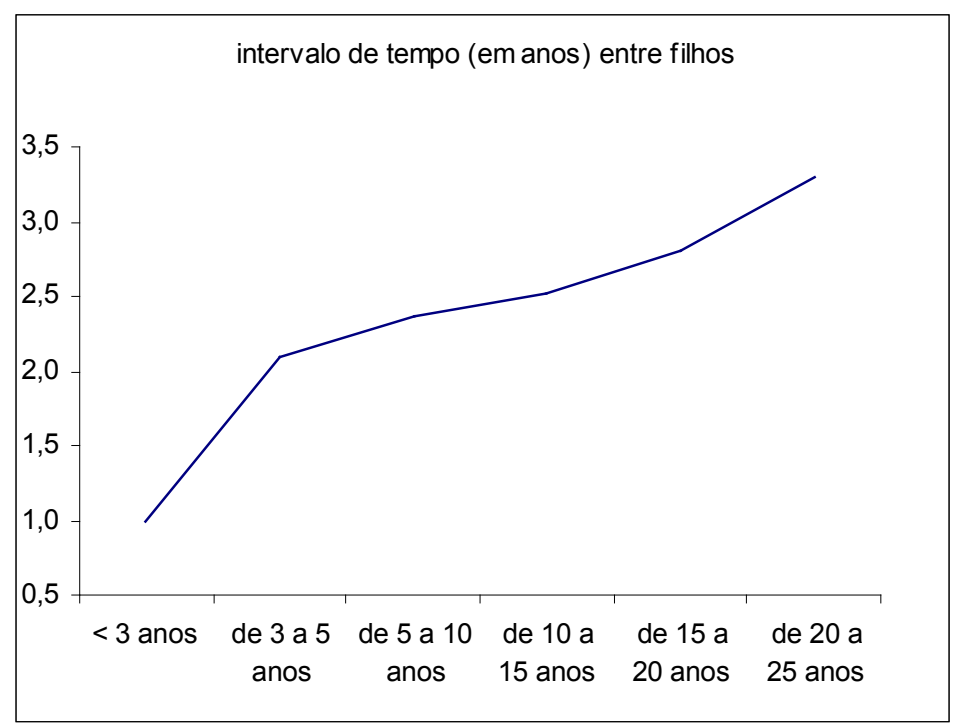

Gráfico 3: intervalo (em anos) entre os filhos, em função da idade dos filhos, nas famílias livres, no termo de Uberaba (1822-1861)

Fonte: APU, 174 inventários do Juizado de Órfãos de Uberaba (1822-1861).

1986). Importava também estimular o crescimento populacional, de forma a ocupar as regiões de fronteira e, assim, impedir que o inimigo espanhol as reivindicasse (MARCílIo, 2000).

Os governos das capitanias reais, contando com colaboradores de Pombal à sua frente, seguiram fielmente a cartilha dos novos tempos. No período de 1750 a 1771, o governador de São Paulo, D. Luís Antônio de Souza, morgado de Mateus, criou catorze novas vilas e povoados naquela capitania, como parte da política de povoamento interior (MArcílio, 2000). Em Minas, na mesma época, o governador Gomes Freire iniciou a guerra contra os quilombos do Oeste Mineiro, para alimpar aquela região, com vistas à colonização.

Com o fim do período pombalino, pela a morte de D. José I, em 1777, a ascensão ao trono português de $\mathrm{D}$. Maria I aprofundou a mudança de rumos na geopolítica colonial. Em 1792, com a loucura de sua mãe, o príncipe regente D. João continuou com a política de valorização estratégica do interior. Estimulou a vinda de famílias do arquipélago de Açores, que foram assentadas em glebas no 
Sul do Brasil; e, em Minas, declarou guerra aos índios botocudos do vale do rio Doce, para que aquela região pudesse ser liberada para a colonização.

No período joanino, restavam ainda, no território da capitania de Minas Gerais, vastas regiões esparsamente povoadas no Leste (Zona da Mata e vales dos rios Doce e Mucuri), no Noroeste (termo da Vila de Paracatu) e no Extremo Oeste (Triângulo Mineiro). O governo de Minas usou então de dois instrumentos poderosos para promover a ocupação dessas regiões: as isenções fiscais e as concessões de sesmarias. Quando da chegada da Corte ao Rio de Janeiro, em 1808, o Conde de Linhares promulgou lei isentando do dízimo, por dez anos, os colonos que se estabelecessem nas regiões ermas de Minas (Saint Hilaire, 2000). Nessa mesma época, começou um verdadeiro boom de concessões de sesmarias pelo governo mineiro, que durou até 1822, tendo por objetivo dirigir o povoamento para as regiões de fronteira.

A instituição sesmeira vigeu por todo o período colonial brasileiro, tendo sido extinta em 1822. As sesmarias eram concessões estatais, mas não dependiam somente das diretrizes colonizadoras do Estado. É falsa a idéia, difundida por Alberto Passos Guimarães (1977), de que apenas fidalgos portugueses e brasileiros enobrecidos recebiam sesmarias no Brasil. A maioria dos sesmeiros não era de origem nobre, e a própria legislação portuguesa, como atesta o foral de Duarte Coelho, de 1534, prescrevia as doações a "a quaisquer pessoas de qualquer qualidade e condição que sejam, contanto que sejam cristãos" (ABreu, 1997, p. 205). Particularmente de meados do século XVIII em diante, não interessava à coroa povoar com nobres, mas simplesmente povoar (GORENDER, 1988).

O principal critério usado nas concessões, e que a própria lei estabelecia, era a possibilidade de cultivo pelos pretendentes. Com o tempo, a posse de escravos tornou-se critério seletivo na aquisição de sesmarias, o que foi colocado textualmente no alvará de 1795, obrigando inclusive a venda ou a alienação daquelas cujos cessionários não tivessem "possibilidades e escravatura" para cultivá-las (GORENDER, 1988, p. 394). Desse modo, colonos que já tivessem acumulado ou herdado alguma riqueza eram preferidos pelos governos das capitanias para obter sesmarias. Em nossa região de estudo, é muito provável que assim tenha ocorrido, pois como pode ser visto nos quadros 1 e 2 , que mostram as sesmarias concedidas entre 1816 e 1822 no Triângulo Mineiro, era grande o número de sesmeiros com cargos eclesiásticos ou detentores de 
postos militares das Companhias de Ordenanças, o que era considerado sinal de distinção pessoal, e, portanto, de certa fortuna (Fragoso, 1998).

A decisão sobre que terras conceder não dependia só do governo colonial. Muitas vezes, o colono inicialmente se apossava das terras, para depois reivindicar a carta de sesmaria a elas correspondente. Assim, os capitãesgenerais apenas ordenavam legalmente ocupações que freqüentemente já haviam ocorrido de fato. Em 1818, por exemplo, o alferes João Pereira da Rocha apossou-se de uma larga extensão de terras entre os rios Uberaba Legítimo e das Velhas (Pezzuti, 1922). Afazendou-se próximo às margens desse último, mas sua carta de sesmaria só foi concedida posteriormente, em 1821, conforme se vê no Inventário de Cartas de Sesmarias do Arquivo Público Mineiro (RAPM, 1988, vol. 2, p. 128).

O gráfico 4, produzido a partir de um levantamento das cartas registradas no Inventário, mostra a distribuição de sesmarias entre 1800 e 1822, em Minas Gerais. Percebem-se dois períodos de intensificação nas concessões: de 1800 a 1802 , e de 1816 a 1821.

É provável que o primeiro pico reflita o êxodo da região auríferometalúrgica de Minas - como vimos, motivado pela pressão demográfica e pelo esgotamento dos solos agricultáveis — gerando uma intensa migração para a comarca do Rio das Mortes. O segundo pico, cujo ápice se deu em 1818, chegando naquele ano a mais de 350 cartas expedidas, possivelmente reflete a política joanina de colonização das fronteiras mineiras.

\begin{tabular}{l|l|l|l}
\hline SESMEIRO & PARAGEM & DATA & OBSERVAÇÃO \\
\hline Antônio de Paiva Lima & Campo Belo & 1818 & alferes \\
\hline Bento de Magalhães Portilho & Mocotó & 1818 & - \\
\hline Brígida Antunes dos & Campo Belo, \\
Santos & $\begin{array}{l}\text { entre os rios } \\
\text { Paranaíba e } \\
\end{array}$ & Tejuco & \\
\hline Fortunato José de Miranda & Ribeirão da & 1818 & - \\
& Bagagem & & \\
\hline Francisco Alvarez & Rio Tejuco & 1818 & padre \\
\hline Manoel Dias da Rocha & Ribeirão da Bagagem & 1818 & - \\
\hline
\end{tabular}




\begin{tabular}{|c|c|c|c|}
\hline \multirow[t]{2}{*}{ Manoel Ferreira Ribeiro } & \multicolumn{3}{|l|}{ Bocaina, no Rio } \\
\hline & da Prata & 1818 & alferes \\
\hline Matheus Cardoso Parreira & Rio da Prata & 1818 & tenente \\
\hline Alexandre Roiz Gondim & Formiga & 1819 & - \\
\hline Hermógenes Casimiro & Sertão & & \\
\hline \multirow[t]{3}{*}{ de Araújo } & da Prata & 1819 & padre \\
\hline & Ribeirão dos & & \\
\hline & Santos Fortes & & \\
\hline João do Vale & e Ribeirão de & & \\
\hline Pereira & São Jerônimo & 1819 & capitão \\
\hline Joaquim Silva e Oliveira & Rio Tejuco & 1819 & tenente \\
\hline José da & Sertão do & & \\
\hline Silva & Rio da Prata & 1819 & - \\
\hline Maximiano José de Andrade & Boa Vista & 1819 & - \\
\hline Miguel Eugênio de Araújo & Lagoa dos patos & 1819 & - \\
\hline Floriano José Marques & Rio Uberaba & 1820 & - \\
\hline Francisca Angélica da & Aldeia Velha, margem & & \\
\hline Silva & do Rio da Prata & 1820 & - \\
\hline Francisco de & Bebedouro & & \\
\hline Paula Teixeira & do Burité & 1820 & alferes \\
\hline Francisco Nogueira Mendes & Douradinho & 1820 & - \\
\hline Ignácio Gonçalves da Silva & - & 1820 & - \\
\hline Januário Luiz da Silva & Ribeirão São Félix & 1820 & - \\
\hline Joaquim Patrício & Rio & & \\
\hline Maxado Roiz & Uberaba & 1820 & - \\
\hline Joaquim Silvério & Ribeirão & & \\
\hline Teixeira de Melo & do Cabaçal & 1820 & - \\
\hline \multirow[t]{2}{*}{ José Francisco de Azevedo } & Rio Piracanjuba e & & \\
\hline & Rio do Peixe & 1820 & - \\
\hline José Joaquim Carneiro & Rio Uberaba & 1820 & capitão \\
\hline
\end{tabular}




\begin{tabular}{llll}
\hline José Luciano & Barra do Douradinho e & \\
Teixeira & Rio da Prata & 1820 & - \\
\hline José Teixeira Alvares & Capão Debaixo & 1820 & - \\
\hline Vicente Nogueira Mendes & Douradinho & 1820 & - \\
\hline Francisco Ferreira da & Ribeirão & & padre \\
Rocha & de São Mateus & 1821 & - \\
\hline Francisco Roiz Rebello & Rio Claro & 1821 & alferes \\
\hline João Pereira da Rocha & Rio Uberaba Legítima & 1821 & - \\
\hline José Alves de Resende & Monjolinho & 1821 & - \\
\hline José Manoel & entre os rios Seco & & alferes \\
da Silva & e da Prata & 1821 & - \\
\hline Manoel Caetano de Menezes & Turvo & 1821 & - \\
\hline Thomé Pinto de Almeida & Santo Antônio e Almas & 1821 & - \\
\hline Demétrio José de Andrade & Rio Uberaba & 1822 & 1822 \\
\hline Joaquim Pereira da Rocha & Morro da Boa Vista & - & - \\
\hline
\end{tabular}

Quadro 1: relação de sesmeiros do Sertão da Farinha Podre (1816-1822). Fonte: RAPM (1988).

\begin{tabular}{|c|c|c|c|}
\hline SESMEIRO & PARAGEM & DATA & OBSERVAÇÃo \\
\hline Maria Pelágia do Carmo & Margem do Paranaíba & 1816 & - \\
\hline José de Resende & $\begin{array}{l}\text { Margens do Paranaíba, } \\
\text { no lugar do Piçarrão }\end{array}$ & & \\
\hline Costa & e da Estiva & 1817 & - \\
\hline Confraria de São & Margens do Rio & & \\
\hline Francisco e & Paranaíba, Ribeirão & & \\
\hline \multirow[t]{2}{*}{ Santo Antônio } & Bom Sucesso & 1819 & - \\
\hline & Margens do & & \\
\hline Antônio José & Paranaíba, pântano das & & \\
\hline de Melo & Araras & 1817 & padre \\
\hline
\end{tabular}




\begin{tabular}{llll}
\hline ssabel Damiana Monteira & Margens do Paranaíba & 1817 & - \\
\hline Lourenço Antônio Monteiro & Margens do Paranaíba & 1816 & - \\
\hline Francelina & Margens do Rio & & \\
Carneira de & Paranaíba, paragem & & \\
Resende & de Piçarrão e Estiva & 1817 & - \\
\hline João Francisco & Distrito da ermida de & & \\
Rodovalho & Santana & 1817 & - \\
\hline $\begin{array}{l}\text { Manoel Francisco } \\
\text { Rodovalho }\end{array}$ & $\begin{array}{l}\text { Distrito da ermida de } \\
\text { Santana }\end{array}$ & \\
\hline José Pereira & Salto do Piçarrão, & & - \\
da Silva & vertente do Rio & & \\
& das Velhas & 1817 & - \\
\hline José Bento & Margens do Paranaíba, & & \\
Soares & no Serrote & 1817 & sargento-mor \\
\hline
\end{tabular}

Quadro 2: relação de sesmeiros do Sertão dos Araxás (1816-1822). Fonte: RAPM (1988).

Se agruparmos as sesmarias por comarcas, como fizemos no gráfico 5 , poderemos visualizar como se deu, por região da capitania, o processo de apropriação pioneira do território. No boom de concessões do início do século, as comarcas que mais tiveram terras distribuídas foram as de Rio das Mortes, Ouro Preto e Sabará, onde se situavam algumas das regiões de fronteira. Nessa época, o Triângulo Mineiro (julgados do Araxá e Desemboque) ainda pertencia à capitania de Goiás. No período posterior, de 1815 em diante, quando se verifica nova onda de concessões, Rio das Mortes tornou-se, indubitavelmente, a região que passou a ser mais intensamente colonizada em Minas. Em segundo lugar, vinha a comarca de Ouro Preto e em terceiro a de Paracatu.

Se analisarmos a distribuição das sesmarias no interior dessas comarcas, agrupadas por termo, veremos que algumas vilas concentravam o processo colonizador, o que torna mais fácil localizá-lo no espaço. Em Rio das Mortes (gráfico 6), na primeira onda de concessões (1800-1803), a maioria delas 


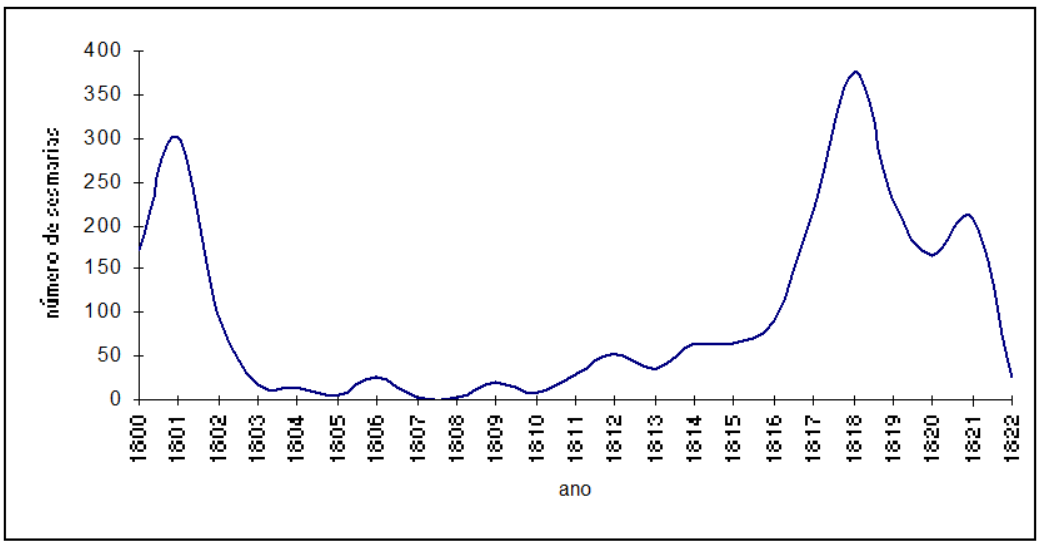

Gráfico 4: distribuição de sesmarias na capitania de Minas Gerais (1800-1822) Fonte: RAPM (1988).

ocorreu no termo da vila do Tamanduá, que incluía a maior parte das terras situadas nas cabeceiras do Rio São Francisco, até a Serra da Canastra, isto é, a região alimpada dos quilombos pelas expedições da segunda metade do século XVIII, e que então vivia os últimos momentos do surto colonizador que se seguiu ao extermínio dos quilombolas. Formava-se ali, dessa forma, uma região agropastoril produtora de alimentos que, como veremos, drenava seus excedentes para o mercado do Rio de Janeiro pela Picada Nova de Goiás e pela Estrada Real.

O segundo pico na curva da distribuição das concessões sesmariais foi praticamente monopolizado, nessa comarca, pelo termo da vila de Barbacena. O vasto território desta vila incluía grande parte do que hoje é chamado Zona da Mata Mineira, e que por essa época sofria intensa ocupação. A pioneira economia agropastoril produtora de mantimentos, responsável pela ocupação daquela área, seria sucedida, a partir dos anos 1840, pela cafeicultura em regime de plantation, tornando-se, com isso, uma das regiões econômicas mais importantes da província, durante o Império.

O gráfico 7 mostra a distribuição das sesmarias na comarca de Ouro Preto. No termo da então capital mineira, praticamente nenhuma carta foi concedida no período em questão, pela óbvia razão de que o território de Vila 
Triângulo Mineiro: uma fronteira na Colônia e no Império

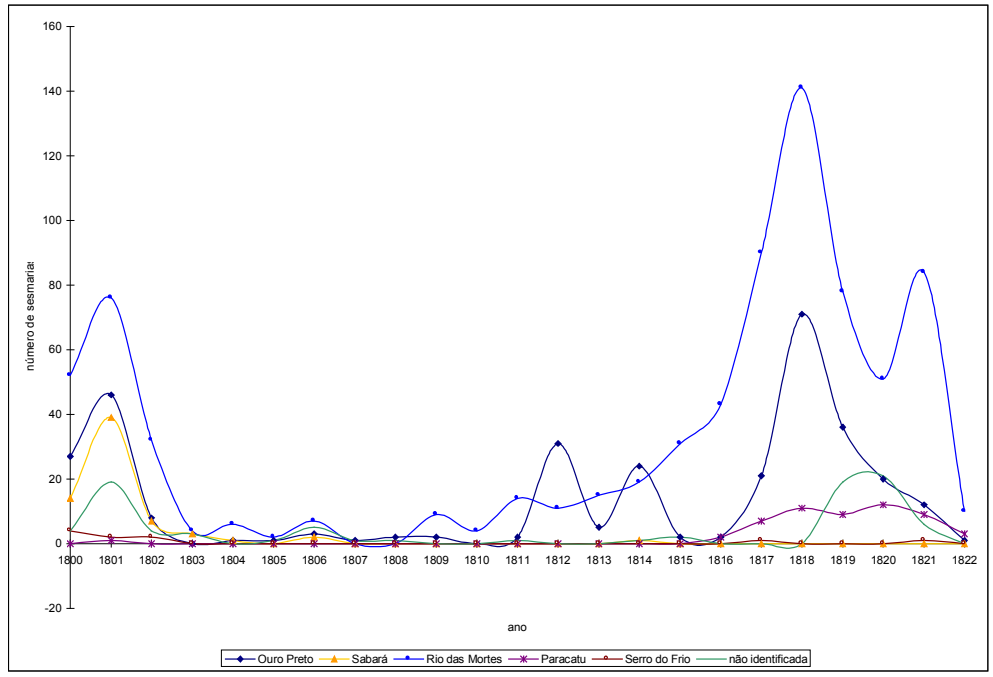

Gráfico 5: distribuição de sesmarias, por comarca, na capitania de Minas Gerais (1800-1822) Fonte: RAPM (1988).

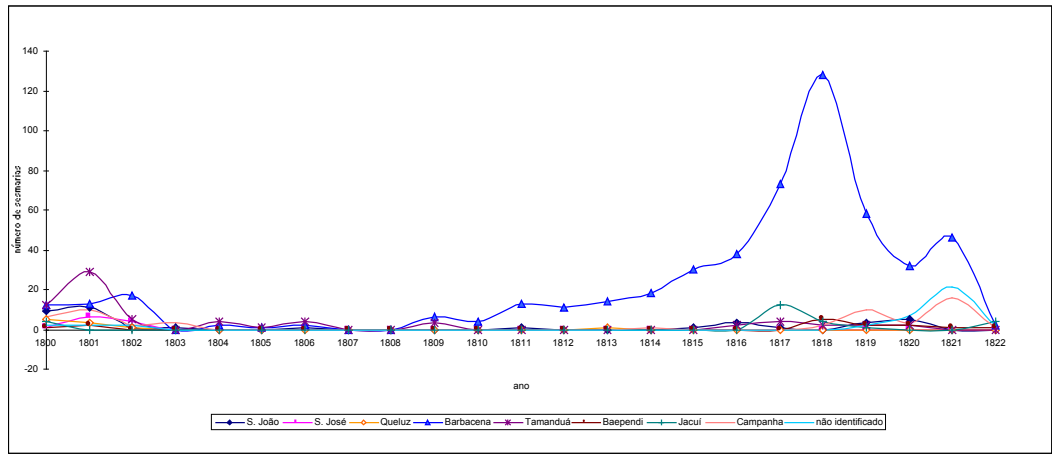

Gráfico 6: distribuição de sesmarias, por termo, na comarca do Rio das Mortes (1800-1822). Fonte: RAPM (1988). 
Rica, intensamente ocupado desde o século XVIII, já não dispunha mais de terras devolutas. A cidade de Mariana, porém, tinha seu termo estendendo-se por quase toda a margem direita do rio Doce, até as divisas com as capitanias do Espírito Santo e Rio de Janeiro, tendo havido ali grande número de concessões.

Desde o final do século XVIII, o vale do rio Doce - parte do termo da cidade de Mariana - deixou de ser considerado "área proibida" pelo governo colonial. O marco dessa nova orientação foi a Portaria de 1784, do governador Luís da Cunha Menezes, dando início à exploração dos sertões do Leste. A partir de então, aquele território tornou-se alvo de intensa colonização, precedida por uma campanha de aldeamento, escravização e extermínio dos índios coroados e coropós (VAsconcelos, 1999). A campanha oficial de colonização continuou nos anos seguintes, no médio rio Doce, com a guerra contra os índios botocudos, promovida, desde 1808, pelo Príncipe Regente (Cunha Matos, 1981). Isso explica porque, durante quase todo o período em questão, mas principalmente após 1810, houve intensa concessão de terras naquele município.

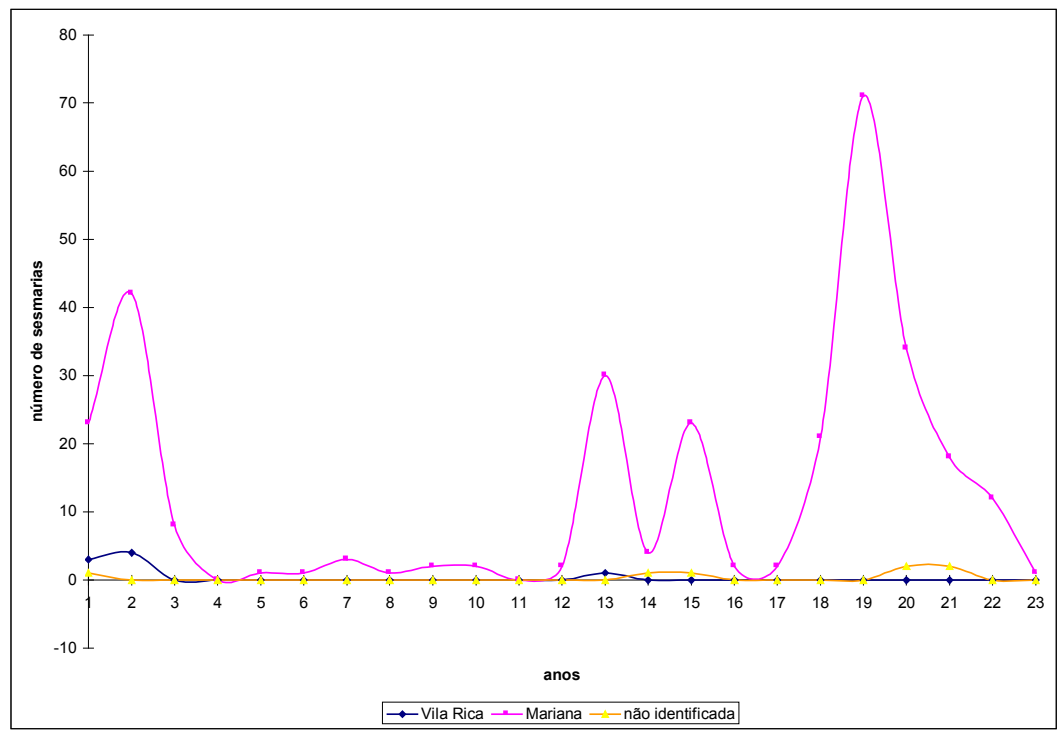

Gráfico 7: sesmarias concedidas, por termo, na comarca de Ouro Preto (1800-1822). Fonte: RAPM (1988). 
A região que estamos estudando, então formada pelos termos dos julgados de Araxá e Desemboque, anexada ao território mineiro em 1816, também foi alvo de uma política colonizadora do governo da capitania, como vimos pelo gráfico 5 (curva da comarca de Paracatu). Na verdade, a comarca de Paracatu, formada pelos termos da vila homônima e pelos julgados de São Romão, Salgado, ${ }^{36}$ Araxá e Desemboque, praticamente só teve terras concedidas nestes dois últimos, sugerindo que a colonização do Noroeste Mineiro (termos de Paracatu, São Romão e Salgado) ainda era muito incipiente (gráfico 8).

O gráfico 8 mostra uma dissociação, tanto no tempo quanto na intensidade, entre as curvas das sesmarias concedidas no Araxá e no Desemboque. Isso não reflete um povoamento supostamente mais tímido dos arredores do rio Paranaíba, mas o fato de a colonização da região araxaense ter se dado, em grande parte, no período da soberania goiana. Nota-se que, no ano de 1817 — ano seguinte à anexação do julgado - , sete sesmarias foram concedidas, o que mostra um processo de colonização em pleno curso. De fato, Saint Hilaire, chegando a Araxá em 1819, três anos após a anexação, relatou que "embora os primeiros habitantes tivessem vindo de Minas Gerais, a autonomia que eles reconheciam era do governo de Goiás. [...] os agricultores podiam obter sesmarias de 3 léguas, que são as concedidas pela província de Goiás" (1975 b, p. 128).

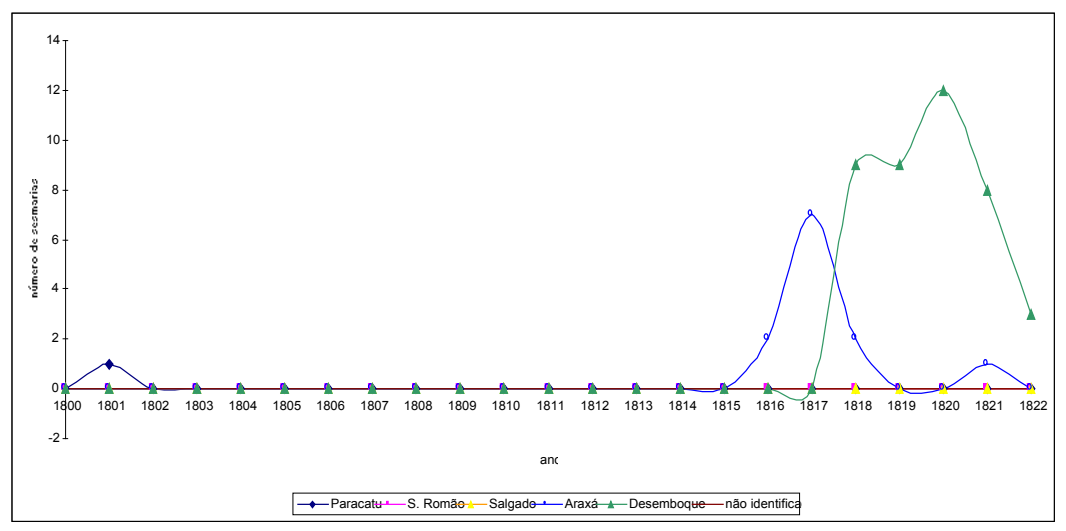

Gráfico 8: distribuição de sesmarias, por termo, na comarca de Paracatu (1800-1822). Fonte: RAPM (1988).

36 Hoje Januária. 
O mesmo gráfico mostra que a colonização do termo do Desemboque (o Sertão da Farinha Podre) começou apenas em 1818, um pouco depois do Araxá. A julgar pelo traçado da curva, é provável que a colonização oficial dessa área tenha sido um empreendimento posterior à sua anexação por Minas, não tendo havido interesse das autoridades goianas em fazê-lo antes. Borges Sampaio (2001) relatou que a primeira sesmaria na região somente foi concedida pelo governo goiano em 1803. Outras concessões certamente foram feitas entre essa data e 1816, pois Eschwege (1996), como vimos, encontrou a região já com oitenta fazendeiros assentados em 1816. ${ }^{37}$ Contudo, elas não parecem ter sido muito numerosas. Não tivemos acesso aos registros das sesmarias goianas para confirmar essa impressão.

As concessões de sesmarias apenas indicam, em linhas gerais, as orientações espaciais do processo de apropriação fundiária, mas não é possível reconstituí-lo apenas pela localização, no território, das extensões concedidas. Maurício de Abreu (1997) mostrou as inúmeras "brechas" do sistema sesmarial, como os posseiros, que ocupavam porções não aproveitadas de sesmarias, e os "restos de sesmarias", áreas devolutas que permaneciam entre os limites das concessões legais e que eram apossadas pelos agricultores. O autor também demonstra que as sesmarias eram freqüentemente subdivididas, por herança ou por venda, havendo um ativo mercado de terras nas regiões mais densamente povoadas. Além disso, muitos sitiantes estabeleciam-se, como veremos, como agregados em terras alheias. Dessa forma, a apropriação fundiária não se limitava apenas às concessões de sesmarias, tendo existido muitas outras formas que escapam às fontes que estudamos.

Pudemos, dessa maneira, avançar na compreensão da geografia da colonização do território de Minas Gerais, nas primeiras décadas do século XIX. O mapa da figura 11 mostra os termos das vilas de Barbacena e Campanha, da cidade de Mariana e do julgado do Desemboque, territórios onde se encontravam, respectivamente, 45\%, 5\%, 23\% e 7\% das 595 sesmarias concedidas entre 1818 e 1822 , perfazendo $80 \%$ do total de cartas. Pela distribuição espacial e cronológica das áreas concedidas em sesmarias,

37 O que significa um número bem menor de sesmeiros, pois, vale lembrar, os fazendeiros sesmeiros eram minoritários, predominando os fazendeiros posseiros e agregados. 
foi possível verificar que o Leste e o Extremo Oeste (hoje Triângulo Mineiro) correspondiam às fronteiras da capitania, naquele período.

Vimos que a instituição sesmarial era um importante instrumento do Estado para promover a colonização de regiões de fronteira, mas era também o reflexo das migrações que para elas se dirigiam, motivadas por fatores outros que não a política oficial. No caso em estudo, esses fatores estavam ligados às tensões demográficas nas regiões de emigração, geradas pelo crescimento de uma população que tinha por base uma economia agropastoril, de nível técnico rudimentar. Resta avaliar, na região em estudo, como se deu a apropriação fundiária sobre terras antes ocupadas por povos indígenas, e os conflitos gerados nesse processo.

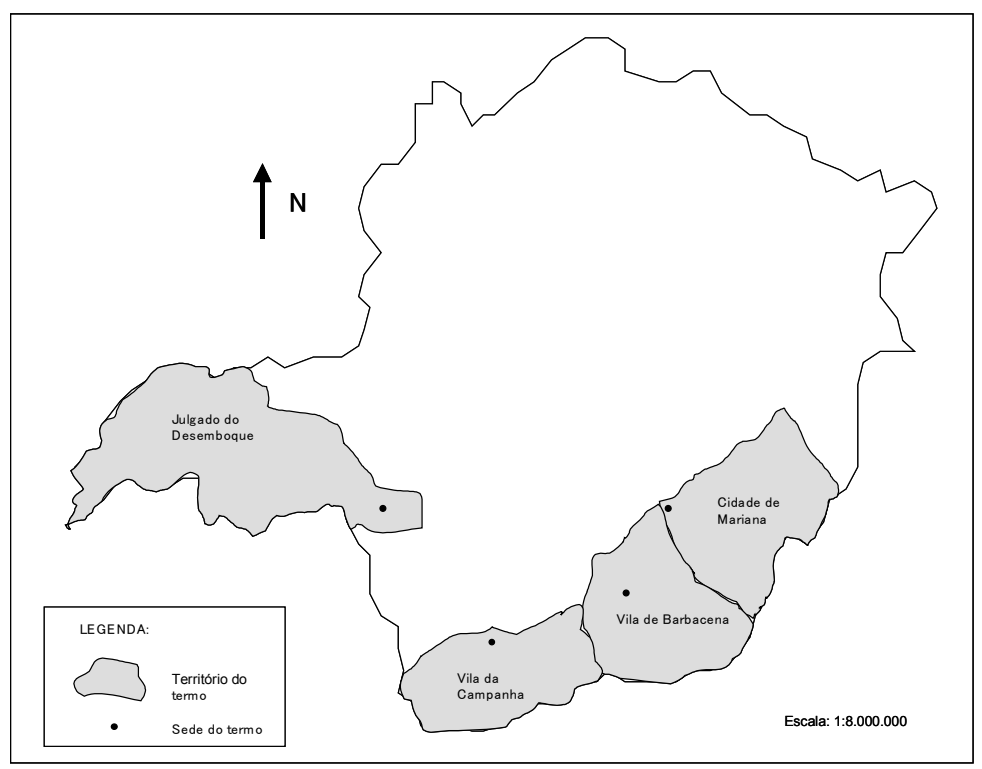

Figura 11: Termos das vilas e julgados correspondentes às principais áreas de fronteira da capitania de Minas Gerais (1818-1822).

Fontes: RAPM (1988), Mendes (2000), Barbosa (1995). 


\section{Geralistas contra índios: o primeiro conflito de terras do Triângulo Mineiro}

Em 1809, o Marquês de Palma, governador da capitania de Goiás, nomeou o sargento-mor Antônio Eustáquio Silva e Oliveira diretor dos índios do Sertão da Farinha Podre (SILVA, 1970). A partir de então, esse fazendeiro empenhou-se, de forma obstinada, em expulsar os índios da faixa de terras de três léguas em torno da Estrada do Anhanguera, para torná-las livres para o assentamento de colonos.

Parte dessas terras já havia sido espoliada, em 1812, ao se propagar, entre os colonos, a versão de que as terras aldeanas estendiam-se por meia légua, e não légua e meia, de cada lado da Estrada. ${ }^{38} \mathrm{O}$ geralista Tristão de Castro, por exemplo, já havia se afazendado, antes de 1812, em terras localizadas dentro da faixa aldeana. Ali, junto com sua esposa, suas duas filhas e mais sete escravos, construiu um sítio com um engenho de cana e uma casa coberta de capim. ${ }^{39}$ A propriedade dessas terras já tinha sido reconhecida nessa data, pois doou parte delas a um patrimônio para ereção da capela de Santo Antônio e São Sebastião, onde seria fundado, quatro anos depois, em terras indígenas, o arraial da Farinha Podre (SAmpaIO, 2001).

Antes de o potentado uberabense Antônio Eustáquio dar o golpe final sobre os direitos fundiários indígenas, em 1821, os viajantes joaninos, que por lá passaram entre 1816 e 1819, encontraram vários fazendeiros já instalados em terras aldeanas, a maioria na condição de foreiros ou agregados. Eschwege (1996), que em 1816 fez o trajeto norte-sul pela Estrada dos Goiases, encontrou, no ribeirão das Furnas, um colono casado com uma índia e instalado na faixa de terras indígenas. Na beira do rio Tejuco, ao longo da Estrada, vivia outro colono, também casado com uma índia e com um filho pequeno (EsCHWEGE, 1996).

A seqüência cronológica dos relatos de Eschwege (1986), D’Alincourt (1975) e Saint Hilaire (1975 a) sobre o sítio da Rocinha ${ }^{40}$ dá-nos uma idéia diacrônica do processo de espoliação dos índios. Na Rocinha, o aristocrata alemão, em 1816, registrou existir uma aldeia com duas famílias indígenas — na verdade, um sítio

38 Essa imprecisão provocou inclusive uma pendência judicial em 1909 entre a câmara de Uberaba e a fábrica da Matriz, pois esta alegava o direito ao patrimônio doado por Tristão de Castro, enquanto a câmara lembrava que as terras dos índios, transformadas em terras devolutas, correspondiam a légua e meia de cada lado da estrada e, portanto, incluíam todo o patrimônio da matriz de Uberaba. (PONTES, 1978)

39 APU, inventário de Tristão de Castro (25/08/1825), maço N21, caixa 459.

40 Hoje Tapuirama, distrito de Uberlândia. 
indígena — que eram "invejadas pelos portugueses da vizinhança" (p. 124), pois dispunham de fontes de água salitrosa para o gado. No ano seguinte, D'Alincourt (1975) não encontrou mais as famílias indígenas, mas a Fazenda da Rocinha, a mesma visitada por Saint Hilaire dois anos depois. Ali, o naturalista francês encontrou um homem que havia chegado há pouco tempo do arraial goiano de Bonfim:

Esse homem [...] viera morar no meio dos índios por razões desconhecidas. Ele me disse, é bem verdade, que achava mais vantajoso viver nessa região, onde os produtos tinham escoamento mais fácil que em Bonfim, o sal era menos caro e as pastagens excelentes (Saint Hilaire, 1975 a, p. 147).

O cronista afirmou, contudo, que o número de brancos nas terras dos índios ainda era pequeno em 1819, pois, nas vizinhanças, ainda existiam terras abundantes (Saint Hilaire, 1975 a). A partir dessa data, com o aumento da imigração dos geralistas, aumentou a demanda fundiária, fazendo crescer, como decorrência disso, a pressão pela espoliação das terras aldeanas.

Eschwege (1996), ao fazer a viagem para a demarcação dos limites da capitania de Minas, em 1816, encontrou-se em Rio das Pedras com o principal $^{\text {11 }}$ daquele aldeamento, um índio chamado Leopoldo. Este lhe disse que os índios de sua aldeia tinham ouvido falar que perderiam seus direitos e suas terras e seriam escravizados. Ao passar por Farinha Podre, encontrou-se com o sargento-mor Antônio Eustáquio, e o apontou como o algoz dos índios da região:

Nas regiões afastadas das capitais e, particularmente nos sertões, encontram-se quase sempre indivíduos que, por meio da inteligência ou de sua riqueza, são superiores aos vizinhos e, de certo modo, conseguem sujeitá-los, embora poucas vezes em benefício da própria comunidade. Também nessa região, um desses tais instituíra-se em soba, cujas ordens valiam, em geral, mais que as do governador, e cujo chicote se exercia mais e mais sobre os pobres índios. Ele comunicou-me que o projeto que tinha em mente, de tomar pouco a pouco a seus índios o seu distrito, para distribuí-lo entre os portugueses, sob o pretexto de que o Rei deles não auferia lucro. (1996, p. 126).

41 Liderança indígena dos aldeamentos. 
Saint Hilaire (1975 a) também não teve boa impressão do potentado uberabense: chamou-o de "pequeno déspota", ao se referir às suas ações antiindígenas.

Um documento assinado por trinta e cinco fazendeiros da Farinha Podre, de 1818, outorgava ao sargento-mor Antônio Eustáquio o poder de comandar a colonização dos sertões sob sua regência, e pedia ao ouvidor da comarca de Paracatu sua nomeação como juiz de sesmarias, o que se deu em 1819 (TeIXEIRA, 2001). A partir de então, ele teria o poder de estabelecer os limites das sesmarias e posses, o que foi usado em favor dos fazendeiros - e em prejuízo dos índios.

Em 1821, os índios apresentaram uma queixa contra os invasores de suas terras, à frente dos quais Antônio Eustáquio, que estavam expulsando a maioria das famílias indígenas que viviam no trecho de terras aldeanas entre o rio Grande e o rio das Velhas (Eschwege, 1996). De fato, algumas sesmarias concedidas nesse período já se situavam dentro de terras indígenas. É o caso da sesmaria de José Alves de Resende, com carta datada de 1821, que se limitava “[...] pelo nascente pela estrada que vai para Goiases, pelo norte com o Rio das Velhas, e pelo sul com o Rio Uberava [Legítimo][...]” (APU, 1987, p. 37). Na mesma data, João Pereira da Rocha, que já havia se instalado numa fazenda vizinha ao rio das Velhas, tomou posse de mais uma porção de terras que se estendiam até o Ribeirão Rocinha, também em área de terras aldeanas (figura 12).

Seria um erro, contudo, acreditar que a expropriação fundiária dos indígenas foi obra apenas de grandes sesmeiros e fazendeiros. Há provas de que também pequenos sitiantes apossaram-se de terras indígenas. À beira do rio Uberaba Legítima, ao longo da Estrada dos Goiases, por exemplo, Saint Hilaire encontrou um velho agricultor, vivendo sozinho e pobremente: "em sua casa viam-se apenas algumas cabaças que lhe serviam de vasilhas, umas poucas panelas e uma pequena provisão de milho destinada a ser vendida aos viajantes" (1975 a, p. 149). O inventário post mortem de Ana Joaquina de Jesus, mulher de João Manuel Garcia, descreve seu sítio como localizado "no Taquaral, em terras da Estrada" ${ }^{42}$ — portanto, na faixa indígena — em 1829. Esse casal de modestos sitiantes não possuía escravos, sendo seu patrimônio formado apenas por dois bois carreiros, um cavalo e uma égua.

Em 1827, os sesmeiros da região do rio das Velhas fizeram uma denúncia

42 APU, inventário de Ana Joaquina de Jesus (16/10/1829), maço N44. 
contra o Fiel do Registro de Santana, que estaria afastando os marcos de sesmaria de dentro da faixa de uma légua e meia ao longo da Estrada de São Paulo, alegando que tais terras pertenciam aos índios. O presidente da província consultou Antônio Eustáquio sobre a questão, e este respondeu tomando o partido dos fazendeiros: “[...] inicialmente as terras próximas à estrada permaneceram desocupadas por se ouvir dizer que pertenciam aos índios da Aldeia de Santana" (Brasileiro, sd, p. 15). Procurou então por Ordem Régia, ou do Governador da antiga capitania de Minas, que concedesse aos índios

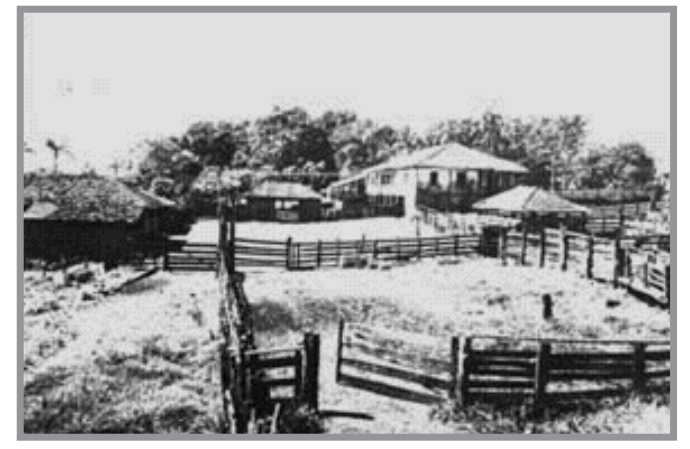

Figura 12: sede da fazenda de João Pereira da Rocha, um dos geralistas que se apossaram de terras expropriadas aos aldeamentos indígenas

Fonte: http://www.uberlandia.mg.gov.br

uma légua e meia de cada lado da Estrada, entre o rio Grande e Paranaíba. Continuou o sargento-mor:

[...] e como não as encontrasse ainda mesmo consultando o Diretório que servisse aos índios, tomei o expediente de franquear todo o terreno às pessoas já mencionadas [os entrantes] para lançar suas posses, reservando todavia meia légua de cada lado da referida estrada para a residência de alguns poucos índios que se achavam dispersos da Aldeia [...] A meia légua reservada também se foi pouco a pouco ocupando até que hoje, porque o povo custa a conter-se, acha-se com mais de mil pessoas o contudo em nada prejudicou, nem prejudica a esses poucos índios já referidos, da Aldeia de Santana os quais tem todo o terreno que se lhes demarcou desde o Rio das Velhas até o Paranaíba em distância de 14 léguas de comprimento com 3 de largura (BrasiLeIro, sd, p. 15). 
O raciocínio usado pelo chefe político uberabense era típico das concepções que informavam a política indigenista do Império, na primeira metade do século XIX: os governos provinciais curvavam-se às pressões exercidas pelos poderes locais, e iniciava-se um processo que Carneiro da Cunha (1998) chamou de politica de concentração dos grupos indígenas. Esta consistia na deportação de índios das reservas para núcleos de adensamento, de forma a liberar as terras indígenas para a colonização.

No caso da Farinha Podre, as ações dos colonos liderados por Antônio Eustáquio - posteriormente referendadas pelo governo provincial — reduziram as terras indígenas de $1.072 \mathrm{~km}^{2}$ (do rio Paranaíba ao rio Grande) para apenas $40 \%$ disso, ou $412 \mathrm{~km}^{2}$ (faixa entre o rio das Velhas e o rio Paranaíba). De acordo com o documento reproduzido por Eschwege (1996), 871 índios foram desalojados da faixa situada no termo de Uberaba e deportados para a faixa do norte, no termo do Araxá, onde se juntaram aos 637 índios que já viviam ali. Com isso, aproximadamente $660 \mathrm{~km}^{2}$ entre o rio Grande e o rio das Velhas foram liberados para a colonização (figura 13). Em 1823, o tenente Inocêncio de Miranda recenseou apenas 67 índios ainda vivendo ao sul do rio das Velhas (BARBOSA, 1995).

Um outro documento, redigido em 1829 e que se encontrava em poder do padre Hermógenes Casimiro de Araújo, vigário do Desemboque e primo de Antônio Eustáquio, deixou claro qual fora a intenção, quando da expulsão dos índios da Farinha Podre. Esse texto resumiu os eventos que se desenrolaram entre 1816 e 1827:

Como essas hordas de índios se fossem diminuindo em número, e o sargento-mor Antônio Eustáquio Silva e Oliveira fosse encarregado por P. do Exmo. Marquês de Palma então Governador da província de Goiás de explorar e acomodar os novos colonos que para os sertões do Tijuco e Rio da Prata e suas anexas mudassem os seus estabelecimentos propôs o dito S. M. ao Governo de Minas [...] que algumas dessas hordas de índios que ainda existiam entre o Rio das Velhas e o Rio Grande, território do Julgado do Desemboque, fossem mudadas para o território do Araxá que fica entre o Rio das Velhas e o Rio Paranaíba (Sampaio, 2001, p. 148).

Adiante, o documento esclarece que toda essa ação de expropriação contou com a chancela das autoridades provinciais, que, em seguida, liberaram o território para a colonização: 
Anexo a esta representação o Governo de Minas, sendo então o Governador da província D. Manuel de Portugal e Castro e por seu despacho mandou que a Reg. dos mesmos índios fizesse mudar essas hordas de índios para o indicado território, como de fato se mudaram. Exaqui como ficando recolhido ao Patrimônio nacional aquele território evacuado das ditas hordas de índios também ficou sendo livre de concessão e aquisição e por isso muitos proprietários nele existentes lançaram posses e levantaram nele seus estabelecimentos que estão possuindo (SAMPaio, 2001, p. 148).

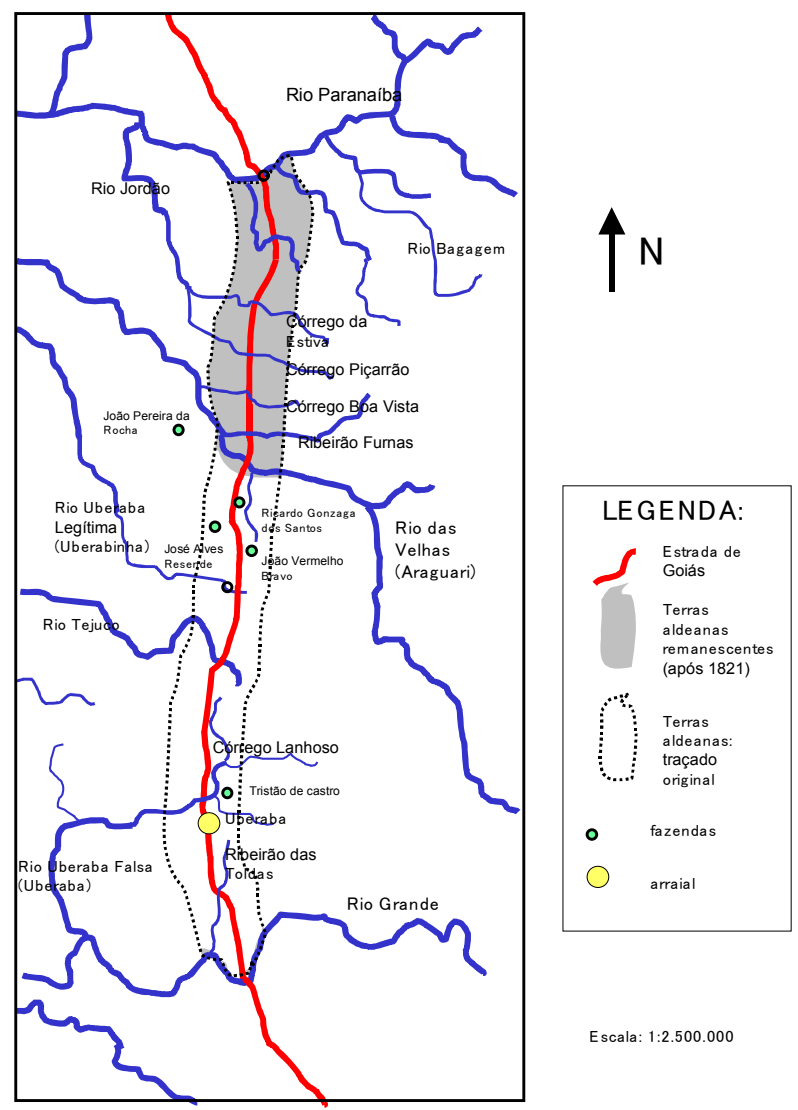

Figura 13: expropriação de terras indígenas no Triângulo Mineiro (1819-1821). Fonte: Eschwege (1996), Sampaio (2001), Teixeira (1970), APU (1987). 
Nossas fontes revelam que alguma resistência foi esboçada pelos índios, durante processo de espoliação a que foram submetidos. As duas queixas, redigidas pelos representantes dos índios aldeados, vistas anteriormente, são um exemplo. Uma outra forma de resistência deve ter sido o uso da violência contra os invasores: D'Alincourt encontrou, próximo ao aldeamento do Lanhoso, uma familia de posseiros brancos "a quem dois índios ali estabelecidos queimaram tudo quanto possuía, e ainda quando passei estava arranchado debaixo de uma coposa árvore" (1975, p. 76).

A espoliação das terras indígenas no termo de Uberaba não era um caso isolado no Brasil do período joanino. Era parte de um processo mais geral, que ocorria em todo o país, particularmente nas regiões de fronteira. A política indigenista pombalina, que estimulava o aldeamento, a aculturação, a mestiçagem e a transformação do índio num povoador, fora definitivamente abandonada com a extinção do Diretório, em 1798. No século que se iniciava, a nova política indigenista seria francamente pior do que a do século XVIII. O índio não interessava mais como força de trabalho, como no século XVII, nem como povoador, como no período pombalino. Suas terras, no entanto, com o crescimento demográfico e a expansão econômica, passaram a ser alvo dos interesses do Estado e da sociedade luso-brasileira. Nas palavras de Carneiro da Cunha:

Porque é fundamentalmente um problema de terras e porque os índios são cada vez menos essenciais como mão-de-obra, a questão indígena passa a ser discutida em termos que, embora não sejam inéditos, nunca haviam no entanto sido colocados como uma política geral a ser adotada. Debate-se a partir do fim do século XVIII e até meados do século XIX, se se devem exterminar os índios "bravos", "desinfestando" os sertões, — solução em geral propícia aos colonos — ou se cumpre civilizá-los e incluí-los na sociedade política — solução em geral propugnada por estadistas [...] (1998, p. 134).

O século XIX, segundo a autora, questionou a humanidade dos índios, muito influenciado pelo pensamento cientificista da época. A guerra justa contra os índios, típica dos séculos XVI e XVII, foi ressuscitada por D. João VI, no combate e extermínio dos botocudos do rio Doce. Na verdade, esses discursos apenas racionalizavam o projeto maior de civilização do espaço, o que, na prática, 
significava o alargamento dos espaços apropriáveis no território. A crescente demanda por terras, em parte resultado da expansão de cultivos de exportação para o interior do país, em parte conseqüência do crescimento demográfico e da expansão do mercado interno, junto com o discurso de desumanização dos índios foram os elementos que levaram às práticas que culminaram no desaparecimento de vários grupos étnicos no Brasil, dentre eles, os bororos, chacriabás e caiapós do Triângulo Mineiro.

Com a transferência da Corte para o Rio de Janeiro, em 1808, o poder imperial passou a ser mais diretamente pressionado por interesses localistas. A questão indígena, por isso, passava cada vez mais da esfera do governo central para as Câmaras Municipais: "são em geral as Câmaras Municipais, cobiçosas de terras, que pressionam no sentido da concentração de índios em poucas aldeias" (CunHA, 1998. p. 144). Como vimos, os interesses da proto-oligarquia uberabense foram o fator que motivou a expropriação das terras aldeanas no Triângulo, de 1816 a 1827. Também aqui, o governo provincial legitimou todas as ações antiindígenas do poder local.

Ao norte do rio das Velhas, na faixa de terras indígenas situada entre este rio e o Paranaíba, os aldeamentos ainda sobreviveriam à pressão dos colonos até a segunda metade do século XIX. Mas também ali, em terras situadas no termo da Vila de Araxá e onde estavam os dois aldeamentos mais populosos - Santana e Rio das Pedras — os conflitos com os colonos brancos já se fizeram sentir nos anos 1830.

Naquele ano, em Santana do Rio das Velhas, o regente do distrito dos índios Manuel José de Almeida dirigiu-se ao Presidente da província denunciando invasores, inclusive o juiz de paz Joaquim Rodrigues de Resende. Segundo o regente, mais de 50 fazendeiros violavam os domínios dos índios. Nos anos seguintes, uma denúncia revelava que dois índios tiveram suas choças incendiadas por capangas a serviço do fazendeiro Antônio do Vale Pereira. Em 1836, a Câmara de Araxá propôs ao governo provincial a dispersão dos índios (BArbosa, 1995).

A população do aldeamento de Santana pouco cresceu nesse período. Em 1838, o núcleo perdeu a prerrogativa de paróquia, após 77 anos (TEIXeIRA, 2001). Em 1843, a paróquia foi restabelecida, e nesse mesmo ano foi visitada pelo mineralogista francês Francis Castelneau, que observou já predominarem os luso-brasileiros na população do arraial: 
a aldeia de indígena só tem o nome, pois hoje é habitada apenas por brasileiros. [...] dispersando-se depois [de fundada] a colônia, que de índia que era, passou pouco a pouco a tornar-se quase portuguesa, com exceção dos poucos descendentes mestiços que ainda se vêm (2000, p. 124).

Três anos mais tarde, um relatório de Uberaba informava que na aldeia ainda viviam 424 índios, mas que as melhores terras de cultura já haviam sido tomadas pelos brancos (BARBOSA, 1995). Tito Teixeira (1970) relatou que, ao tempo da Guerra do Paraguai (1865-1870), índios de Santana ainda eram vistos cultivando algumas roças na margem direita do rio das Velhas. As referências aos índios dessa região desaparecem das fontes a que tivemos acesso, a partir dessa data.

$\mathrm{Na}$ verdade, as terras indígenas, submetidas a grilagens desde 1821, permaneceram devolutas até bem recentemente. Existe uma esclarecedora carta do técnico agrícola José Carlos Pedro Grande, destinada ao historiador araguarino Calil Porto, que indica a forma como provavelmente se dava a expropriação indígena. ${ }^{43}$ José Carlos havia sido assistente do $7^{\circ}$ Distrito de Terras e Colonização, sediado em Uberaba, em 1914, e fora chamado para regular a situação das terras ditas aldeanas, próximas ao distrito de paz de Santana do Rio das Velhas, já então no município de Araguari. Identificou-as como se estendendo "do Porto do Registro [no rio das Velhas] até o Porto Mão de Pau [no Rio Paranaíba], légua e meia para cada lado da estrada [do Anhanguera]".

Inúmeras invasões teriam ocorrido na tal faixa após o fim do regime de sesmarias, em 1822. Com a Lei de Terras, em 1854, as paróquias passaram a poder registrar no livro das freguesias "as terras ocupadas pacificamente". Diversos desses registros haviam sido examinados pelo técnico, mas, em 1910, a paróquia de Santana os queimou, pois o Bispado de Uberaba estava envolvido numa questão de terras. O agrimensor lembrava-se, contudo, de que as posses haviam se limitado às terras de cultura, e campos e chapadões permaneciam, ao tempo do seu trabalho, devolutas.

Assim permaneceram até bem recentemente, como mostra um artigo publicado num jornal de Uberlândia em 30 de Janeiro de 1939, escrito pelo agrimensor e então prefeito de Indianópolis, Nelson Soares de Oliveira,

43 José Carlos Pedro Grande, carta a Calil Porto, 1962, originais de Calil Porto, vol. 3, p. 8, Arquivo Público de Araguari. 
envolvido numa disputa de divisas com o município de Araguari.

De forma alguma a estrada do Anhanguera passa na cabeceira do Santo Antônio, estando desta cabeceira afastada 10.000 metros aproximadamente. Esta estrada ninguém a conhece como eu: levantei-a toda, pelos seus marcos de pedra de 1 metro de altura, existentes há mais de 70 anos, para subdivisão das terras devolutas que circundam a mesma. Isto é, todas as terras situadas a légua e meia portuguesa da mesma são devolutadas. O limite da légua e meia do lado de quem sobe de Indianópolis para o Paranaíba ainda está a mais de 900 metros da cabeceira do Córrego Santo Antônio. A prova real disto é que deixei a fazenda do Santo Antônio como legítima por estar a mais de légua e meia da estrada do Anhanguera (Oliveira, 1939).

A posse livre de terras, que perdurou entre o fim das sesmarias e a Lei de Terras de 1850, foi talvez a brecha da qual muitos colonos se aproveitaram para expropriar terras aos índios, na faixa aldeana ao norte do rio das Velhas. O fato de a maioria dessas terras serem de cultura torna pouco provável que a posse tenha sido pacífica.

Sobre a Aldeia do Rio das Pedras, temos poucas informações entre o último registro de Saint Hilaire, em 1819, e a criação do distrito de paz em 1890. Um Decreto Imperial de 1854, vigente até 1856, reconhecia, no distrito de Rio das Pedras (então município da vila da Bagagem ${ }^{44}$ ) uma demarcação de uma faixa de terras de cinco por três léguas como reserva dos índios (FERREIRA, 1959), com certeza, o trecho em torno da Estrada do Anhanguera. Uma Carta de Minas Gerais, produzida pelo engenheiro Henrique Gerber a pedido do presidente da província, em 1862, mostra Rio das Pedras e ainda os aldeamentos de Boa Vista, São Domingos e Lanhoso (figura 14). Os demais já haviam desaparecido

$\mathrm{O}$ que parece certo é que os aldeamentos não evoluíam diretamente para arraiais. A pobreza indígena, o fato de serem habitats rurais concentrados e não aglomerados pré-urbanos, a expropriação de terras e a exploração em regime de semi-escravidão, o estigma de índios, tudo isso contribuiu para a forte tendência centrífuga dos aldeamentos, fazendo com que nunca passassem de um aglomerado de casebres e uma capela freqüentemente em ruínas.

$\overline{44 \quad \text { Hoje Estrela do Sul. }}$ 
Alguns aldeamentos desapareceram sem deixar vestígios, como Estiva, Piçarrão, Boa Vista e Lanhoso. Outros tiveram seus sítios ocupados por povoados ou cidades, mas sem nenhum tipo de continuidade com o espaço e a sociedade criados pelos índios, como Rocinha e a Aldeia de Uberaba. Outros só começaram a evoluir para arraiais no momento em que deixaram de ser considerados aldeias, fazendo com que pouco a pouco se diluísse o

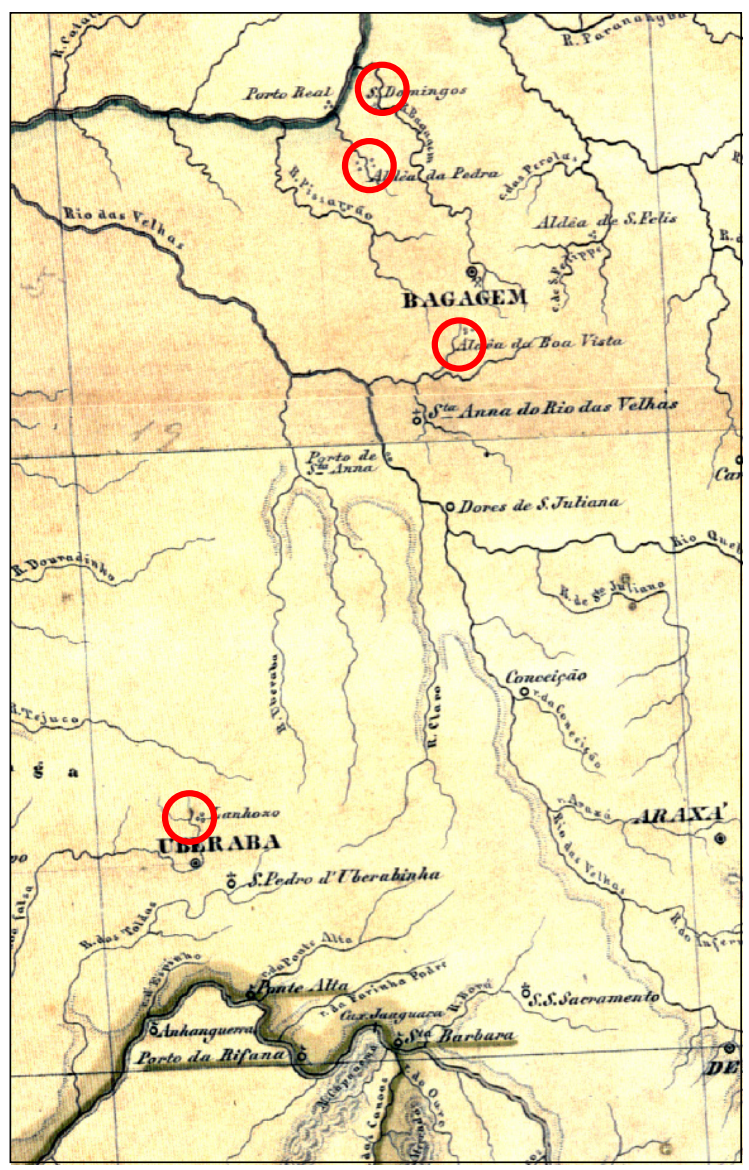

Figura 14: Aldeamentos do Triângulo Mineiro no mapa de Gerber (1862) Fonte: Gerber (1862) 
estigma de indios. A partir daí, estes foram sendo substituídos ou fundiramse com os invasores brancos, como no Rio das Pedras e em Santana. Nossa conclusão, ao se estudar todos esses casos, é a mesma de Petrone:

[...] na realidade o papel dos aldeamentos para o povoamento em última análise foi diminuto, dado que, a não ser poucas exceções, durante séculos não deram margem ao surgimento de núcleos urbanos. [...] considerada a natureza de suas funções, os aldeamentos dificilmente poderiam evoluir dentro dos padrões comuns aos povoados frutos das iniciativas dos moradores europeus. A natureza de aldeamento distinguia-os dos povoados de moradores brancos, estes podendo evoluir para condições rururbanas desde que tivessem possibilidades para isso, aqueles permanecendo com suas características originais. A prova está no fato de que, somente quando a tutela dos indígenas deixou de existir, com a abolição da condição de aldeado, é que os núcleos puderam evoluir dentro de padrões comuns aos restantes (1995, p. 341).

Ao mesmo tempo em que as oligarquias uberabenses se esforçaram em colonizar o Sertão da Farinha Podre, à custa da expropriação dos índios aldeados em torno da Estrada do Anhanguera, houve a iniciativa de aldear os últimos remanescentes de índios caiapós que ainda viviam no baixo rio Grande. Não há paradoxo nisso: aldear os últimos caiapós significava dar continuidade à política de concentração dos grupos indígenas, de forma a liberar seus territórios à colonização.

Eschwege (1996) relatou que esses índios ainda atacavam colonos em 1816, e em 1826 Antônio Eustáquio enviou notícias sobre uns mil caiapós que povoavam as margens do rio Grande (CÉSAR, 1975). Mas, em 1827, o padre Leandro Rabelo Peixoto e Castro só encontrou índios dóceis e fragilizados (PONTES, 1978). Nessa data, o padre fora enviado pela Congregação da Missão São Vicente de Paulo, com sede no Caraça, para fundar um colégio no patrimônio doado pelo fazendeiro João Batista de Siqueira na região do Campo Belo, ${ }^{45}$ entre os rios São Domingos e Verde, afluentes do Grande. O padre Leandro contatou os índios caiapós, e em carta ao presidente da província, relatou sua experiência:

45 Hoje Campina Verde. 
Tive fala com os índios caiapós, e apesar de só por intérprete lhes falava, achei neles as melhores disposições, batizei quatro meninos com consentimento de seus pais aos quais não batizei por não terem instrução, mas os convidei e consegui que viessem morar junto da nossa habitação, lhes fiz arranjamentos, os vesti e dei as providências para que com eles mesmos se fizesse roça e plantasse mandioca para o seu sustento, enfim eu os vi chorar quando deles me apartei [...]. O padre David é quem ficou à testa desse aldeamento que dista 32 léguas de Santo Antônio de Uberaba e 5 léguas do Rio Grande quase junto ao Parnaíba (Pontes, 1978, p. 89-91).

Naquele local, o padre vicentino fundou um aldeamento, onde foram reduzidos os últimos caiapós do Triângulo Mineiro. Vigário Silva, em sua História Topográfica, referiu-se a 1.000 índios caiapós aldeados a 30 léguas de distância do arraial de Uberaba. Tratava-se certamente do aldeamento vicentino e, por suas informações, sabemos que Antônio Eustáquio também dirigia aquele núcleo:

Estes índios caiapós passeiam de tempos em tempos por toda a freguesia, mas não cometem a menor hostilidade, o que se deve sem dúvida ao jeito e ao amor com que têm sido tratados pelo sargento-mor Antônio Eustáquio da Silva, que os visita todos os anos, prodigalizando-lhes roupa e ferramentas, ora a sua custa, ora a custa da Fazenda Pública (SiLva, 1970, p. 9).

Com a redução dos últimos caiapós, o sertão dos baixos cursos dos rios Grande e Paranaíba, região hoje conhecida como Pontal do Triângulo Mineiro, estava livre para a colonização. Povoações novas foram surgindo, como Campo Belo, e do outro lado do rio Paranaíba, na província de Goiás, o arraial de Santana do Paranaíba, ${ }^{46}$ núcleos que tornaram possível a abertura da estratégica estrada do Piquiri, ligando Uberaba ao Campo Grande da Vacaria. ${ }^{47}$

A tendência demográfica do núcleo caiapó, como os demais, também foi de despovoamento. Em 1846, padre Jerônimo Gonçalves de Macedo batizou o aldeamento caiapó com o nome de Missão de São Francisco de

46 Hoje Paranaíba, no estado do Mato Grosso do Sul.

47 Hoje Campo Grande (MS). 
Sales, ${ }^{48}$ que em seu tempo contava com apenas 200 índios (BArBosa, 1995). Em pouco tempo, também na Missão os índios desapareceriam: o mapa de Gerber, de 1862, já não menciona mais S. Francisco de Sales como aldeia, e sim como arraial, o que torna provável que, naquele momento, os índios já fossem minoritários frente aos colonos no núcleo.

Parte desses índios foram deslocados para a Aldeia da Baixa, um dos aldeamentos bororos recenseados por Eschwege, a três léguas ao sul de Uberaba. Um documento de autoria anônima, datado de 1866, citado por César, referia-se aos caiapós da Baixa:

Sendo em outro tempo agressores e cometendo não pequenas hostilidades, hoje se conservam na maior quietação depois que os reduzi à amizade, dando-lhes roupas, ferramentas e algumas quinquilharias (1975, p. 308). ${ }^{49}$

E adiante, outro trecho sugere que a aculturação (ou civilização) era a intento ao se reduzir índios tão próximo a Uberaba, um argumento coerente com o discurso ilustrado da época, que propunha a miscigenação dos índios e sua assimilação pela sociedade brasileira:

Dê-se uma légua de terra a uma grande família de índios; dê-se uma légua vizinha a um brasileiro de grande família; assim se vão entrelaçando e civilizando sem maior despesa da Nação que deve, contudo, dar um pároco que sirva para os índios e para os brasileiros (CÉSAR, 1975, p. 308).

Na Corografia Histórica de Cunha Matos, de 1837, lê-se que caiapós ainda atravessavam com certa freqüência o Paranaíba, próximo da foz desse rio no Grande, e que "há poucos anos fizeram grandes depredações nessa comarca e na do rio das Velhas, mas agora raríssimas vezes penetram no rio Paranaíba" (1979, p. 55-56).

$\mathrm{O}$ último registro sobre os caiapós na região data do século $\mathrm{XX}$, feito pelo etnólogo Curt Nimuendaju: “em 1910 [a tribo] estava reduzida a umas trinta e tantas pessoas, em ambas as margens do rio Grande, abaixo

48 Hoje São Francisco de Sales.

49 José Vicente César, Índios de Minas Gerais por ocasião da Independência, Revista do Instituto Histórico de Minas Gerais, vol. XVI, 1975, p 308 
do Salto Vermelho, a $19^{\circ} 50^{\prime} \mathrm{S}$ e 50 30' O” (1982, p. 219), a $50 \mathrm{~km}$ a oeste da Missão de São Francisco de Sales, nas proximidades da atual cidade de Iturama.

Mas afinal, para onde foram os índios? É muito provável que tenham tido o mesmo destino dos índios dos aldeamentos paulistas, a respeito do qual Petrone (1995) e Monteiro (1994) concordam: a caboclização, isto é, a fusão com o campesinato pobre da região. Ao emigrar dos aldeamentos, fugiam da pobreza, do esgotamento de terras, da violência e do estigma de casta de indios. É provável que tenham se incorporado à massa de agregados pobres e posseiros que gravitavam em torno das grandes fazendas na região, e tenham se tornado, com o tempo, indistinguíveis deles. Tivemos a oportunidade, em outro trabalho, de reproduzir o relato de um antigo morador do meio rural de Uberlândia, Sr. Oscar Jacinto de Souza, nascido em 1894, que afirmava ser neto de uma índia da Aldeia de Santana (Lourenço, 1986). Na verdade, quantos de nós, no Triângulo Mineiro, não temos na família uma história de descendência de uma índia "pega no laço"?

Neste capítulo, procuramos entender o movimento migratório de roceiros e criadores que, vindos da região aurífera de Minas, povoaram a região em estudo, nos últimos anos do século XVIII e primeiros anos do século XIX. Vimos que os fatores de natureza demográfica e ambiental estavam na base das motivações daquela migração. O Estado teve participação central nas diferentes fases do processo de colonização, das áreas de fronteira do território mineiro, como o Sertão da Farinha Podre: nas campanhas contra os quilombos, no século XVIII; na concessão de sesmarias; na política indigenista; na abertura de picadas e estradas. A migração tomava a forma de deslocamentos de núcleos familiares, às vezes organizados em parentelas, fundamentais ao estabelecimento de redes de solidariedade, na região de chegada. A chegada dos migrantes geralistas no Triângulo Mineiro, porém, provocou a expulsão dos índios que ali viviam, e a destruição dos seus aldeamentos.

Analisamos, enfim, a gênese da configuração territorial do Triângulo Mineiro oitocentista. Resta estudar a espacialidade produzida por essa sociedade, isto é, a forma como ela, no ambiente do Cerrado do Triângulo Mineiro, de posse de um dado complexo de técnicas, dispondo de determinados 
Triângulo Mineiro: uma fronteira na Colônia e no Império

referenciais culturais, e inserida numa certa estrutura econômica territorial e mundial, produzia formas espaciais específicas. Abordaremos, no capítulo que se segue, o meio técnico no Triângulo Mineiro do século XIX. 